\title{
THE CREVICE FAUNAS OF THE UPPER INTERTIDAL ZONE AT WEMBURY
}

\author{
By J. E. Morton \\ Department of Zoology, Queen Mary College, University of London
}

(Text-figs. I-7)

The main picture of the zonation of life between tide marks on British shores has been added to by a good deal of recent work, such as that of Colman (1932) and Evans (1947) at Plymouth, and the regional studies by Stephenson \& Stephenson (1949). Of the more restricted special habitats within the tidal area there have been fewer accounts, though Colman (1940) has made a detailed survey of the faunas inhabiting intertidal seaweeds, which was later followed by Wieser (1952). Most recently there has appeared a paper by Glynne-Williams \& Hobart (1952), working at Anglesey, which for the first time analysed clearly the composition and food relations of the restricted fauna living in crevices in this habitat. This part of the tidal zone forms an interesting meeting place of two faunal elements, those intertidal animals of terrestrial origin and those which are truly marine. In the summer of 1950 and I95I the present writer had made a similar study in the Plymouth area, at Wembury and some other localities. The work was begun as part of an ecological study of the two marine pulmonates Leucophytia bidentata and Otina otis, and was later extended to take account of the other animals hidden in crevices and those living on the exposed rock surface throughout the upper half of the tidal zone.

The work of Glynne-Williams \& Hobart lends a further interest to the Devon results as a comparative study, and-while in many respects both this and the Anglesey work must serve as preliminary studies only-the following account may be of value (i) in making a comparison with the larger and welldeveloped crevices in another type of foliaceous rock, (ii) in giving some quantitative data on the vertical and horizontal distribution of animals in crevices, (iii) in showing the differences in detail between the essentially similar crevice faunas in the two localities, and (iv) in making a comparison between conditions applying to ecological succession in crevices with conditions of life on the open rock surface.

The seaweed-inhabiting faunas are not further discussed here, with the single exception of the lichen Pygmaea pumila (=Lichina pygmaea). The observations of Glynne-Williams \& Hobart on the origin, and the food and moisture content of the deposits present in crevices are also taken as broadly 
applicable to Devon conditions, and here again the present writer has no new contribution to make.

This work was carried out at the Plymouth Laboratory of the Marine Biological Association, where I enjoyed the use of the University of London Table. I am grateful to Mr F. S. Russell, F.R.S., and the Plymouth Staff for much assistance, and in particular I have to thank Mr G. M. Spooner for the identification of many of the crustacea and Mr F. G. C. Ryder for help with the levelling of the area. Mr T. E. Hughes of Birkbeck College, London, was kind enough to identify the mites, and my special thanks are due to Prof. A. Graham for his continued kindness and encouragement while I was a research student at Birkbeck College during I95I and 1952.

\section{The Locality and Classification of the Habitats}

The principal area studied was the rocky shore at Wembury, near Plymouth, where on either side of a small sand-beach two reefs run seaward in a southwesterly direction, Church Reef as discussed and surveyed by Colman (I932) and a similar reef immediately to the west. Both reefs are composed of Dartmouth Slates, and form near the landward edge a series of strongly projecting ledges, obliquely overthrust chiefly towards the north or north-west. The geological formation of slates is perhaps the most ideal for a study of crevice-dwelling animals, the successive slabs weathering apart to form narrow, oblique fissures often as much as $\mathrm{I} 2 \mathrm{in}$. deep. The survey was confined to rocks above mean sea-level which is at $8.2 \mathrm{ft}$. above Chart Datum (C.D.) zero for Plymouth. Re-levelling of the portion of the area studied in detail was carried out, and the tidal levels have been taken to be those determined for Wembury by Colman (I932). As in that paper and in the work of Orton (I929), a height of $2 \mathrm{ft}$. has been allowed for the raising of effective water-level by the action of wave surge and splash. Following Colman (I932) heights above C.D. have been expressed throughout in feet.

A typical portion of the ground selected for sampling is shown in the profile diagram (Fig. I) drawn from an outcrop of rock near the landward edge of the west reef. Here there is a vertical range up to $22 \mathrm{ft}$. above C.D. On the topmost outcrops of rock, above $20 \mathrm{ft}$. C.D., which were never covered by the tide or regularly subjected to wave splash, the surface is brightly daubed with the yellow terrestrial lichen Xanthoria. Down to $c$. $16 \mathrm{ft}$. C.D., a little way above MHWS the tarry black lichen, Verrucaria maura, encrusts most of the rock, being sprinkled at the lower limits with tufts of the bushy lichen Pygmaea pumila. From here down to $c$. Io ft. C.D. there is a continuous zone of the barnacle Chthamalus stellatus, intermixed especially at the lower half with more tufts of Pygmaea. Below c. Io ft. C.D. species of Fucus form a thick covering, in most places continuous, on the flatter rock surfaces, and there is 


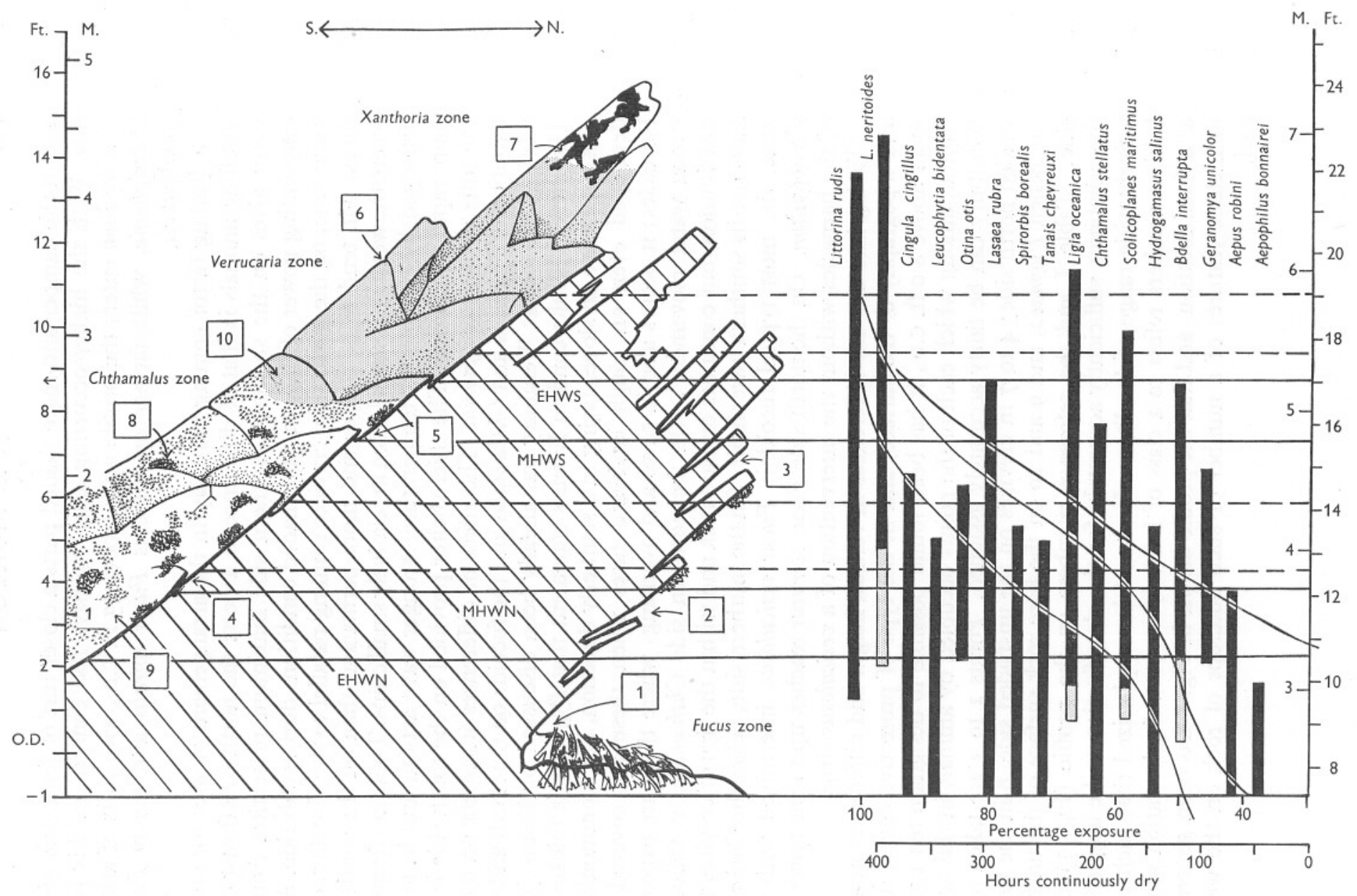

Fig. I. Generalized diagram with a profile section of portion of an outcrop of Dartmouth Slates at the landward edge of the west reef at Wembury, showing typical positions for locations I-IO referred to in Table I (p. I9I). Tidal levels have been superimposed on the profile, the broken lines representing splash levels $2 \mathrm{ft}$. above the respective tidal heights. On the right are shown the vertical ranges of some of the commoner crevicedwelling and other animals. A stippled portion of a column represents an extension of range on the exposed southward side. On the right are shown (below) the two curves for percentage of exposure at various levels, the 'splash curve' being the higher, and (above) the curve for the maximum period of continuous exposure (see Colman, 1932). 
also in the damper and more shaded parts a closer turf of Laurencia pinnatifida. With the higher-occurring algae we have less concern in this paper; Ascophyllum enters the profile up to about I3 ft. C.D., with tufts of attached Polysiphonia, while farther up there is Fucus spiralis and finally Pelvetia canaliculata.

A leading factor coming into play in the arrangement of sites for crevicedwelling animals is that of difference in aspect: the north overthrust of the slates gives on the sheltered northern side maximum protection from the evaporating power of the sun, and shaded conditions during ebb-tide. At the same time, on the north side, crevices running parallel to the direction of the thrust will tend to be deeper and more permanent than on the south side, where the weathered slates loosen in relatively small chips. These are frequently dislodged by extremes of temperature, stronger wave action, and in general more rapid weathering. The chief shelter provided on the south side is from the tufts of Pygmaea pumila. The effect of differences in aspect on the distribution of Pygmaea and Chthamalus and the fucoids on the north and south faces of the reef at Wembury has already been discussed by Evans (1947). The present results confirm Evans's statement that Pygmaea is thickest and most extensive on slopes facing in a southerly direction, but 'commonly well developed even on rough landward faces when these are covered with barnacles; it occurs also in caves and overhangs where these are exposed to strong water movement'. On the northern side Chthamalus is thinner in distribution, but continues on bare rock and within the lips of crevices to not far above its southern lower limit. On the southern side, below the Chthamalus zone, the most typical fucoid is Fucus vesiculosus, intermixed with some Ascophyllum. On the north side Fucus serratus reaches up to the lower limit of the barnacles without the intervention of a vesiculosus strip.

Taking into account differences in vertical height and differences in aspect and topography of the surface, and in the type of protective cover, on the rocks above $8.0 \mathrm{ft}$. C.D., it has been found possible to designate ten types of habitat, among which each of the points occupied by animals in this zone at Wembury can be fairly accurately assigned. Points $\mathbf{I}$ to 3 are taken on the shaded north side; 4 to 7 in crevices on the unshaded side, 8 in the tufts of the lichen Pygmaea, and $\mathbf{9}$ and ro on the bare rock surface of the unshaded side. Table I and the reference numbers on the profile (Fig. I) define these habitats sufficiently accurately for the classification to be applied over a fairly wide range of localities. It should be emphasized that each of the habitat numbers refers to a class of habitat, not to a single station sampled at a fixed location, and that the profile drawn in Fig. I has been generalized to include features of a number cf such outcrops of rock on the western reef. 
Table I. Classification of Habitats in Upper Tidal Zone at Wembury

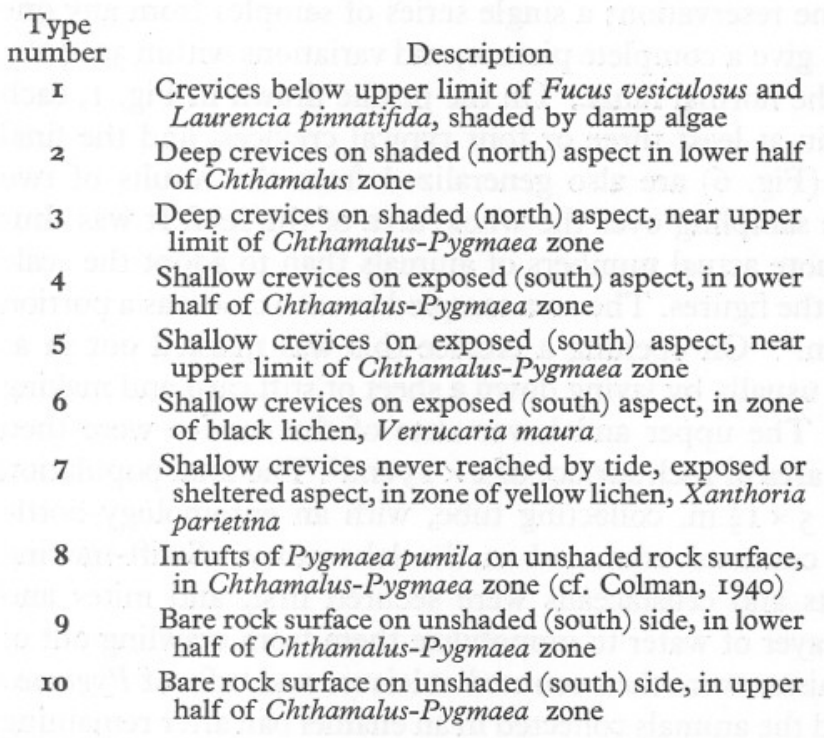

Tidal levels (c.D.)

c. ro ft. and below

EHWN to MHWN, c. 10.5I $2.5 \mathrm{ft}$.

Around splash zone of MHWN, c. $14.5 \mathrm{ft}$.

EHWN to MHWN, c. 10.5$12.5 \mathrm{ft}$.

Around splash zone of MHWN, c. I4. $5 \mathrm{ft}$.

Around splash line of MHWS, c. $\mathrm{I} 7-\mathrm{I} 9 \mathrm{ft}$.

c. $20-22 \mathrm{ft}$.

c. II-I4 ft.

EHWN to MHWN, c. 10.5I $2.5 \mathrm{ft}$.

c. $\mathrm{I} 3-\mathrm{I} 6 \mathrm{ft}$.

\section{Method-SAMPLING Procedure}

In attempting to give a quantitative estimate of the faunas present in each of the locations selected, several difficulties arise which are not experienced on the more uniform environment of a soft-bottomed shore, where the classical methods of notation are best brought into use. First, the environment is never entirely uniform or perfectly comparable in detail from one station to another. There is every gradation of such variable factors as differences of shade, differences of crevice substratum and differences in shelter from wave attack. On moving from one outcrop of rocks to another, often not even a rough replica of the previous environment is obtainable. Secondly, there is the extreme patchiness of many of the species themselves, even in environments that appeared to be approximately uniform. Thus the excursions made by the mite Bdella between crevices 4 and the bare rock surface vary extremely from hour to hour. Anurida maritima, to take another example, is sometimes present in several hundreds in one crevice and is likely to be quite wanting in another close by. With Otina and other animals aggregating together, perhaps a dozen may be found in a favoured part of a crevice and in a sample of another part altogether missed. Further, such very abundant dominants as Lasaea rubra vary within wide limits in apparently replicate areas-this is exemplified by Colman's three counts of Lasaea from $50 \mathrm{~g}$. of Pygmaea. None the less, it would be misleading not to recognize in general a fairly constant relationwith large enough series of samples-between crevices of comparable locations. This tends to hold good over Wembury and other Plymouth localities 
as well, and to vary in roughly the same way with gradations in ecological conditions. There is one reservation: a single series of samples from any one chosen station may not give a complete picture, and variations within 30-40\% are to be regarded as the normal range. On the profile drawn in Fig. I, each location was sampled in at least three or four typical crevices, and the final distribution diagrams (Fig. 6) are also generalized from the results of two seasons' representative sampling over the whole area of the reef. It was thus found less useful to quote actual numbers of animals than to adopt the scale of densities as given in the figures. The area sampled in each case was a portion of the crevice of $15 \mathrm{~cm} .{ }^{2}$. On opening a crevice this was marked out in as quick time as possible, usually by laying down a sheet of stiff card and making marks at each corner. The upper and lower slate of the crevice were then sampled, giving a total area of rock surface of $2 \times 15 \mathrm{~cm} .{ }^{2}$. The total population was sucked up into a $5 \times 1 \frac{1}{2}$ in. collecting tube, with an entomology-bottle glass intake, and the contents examined in the laboratory. Swift-moving animals such as insects and crustaceans were secured first, and mites and insects drawn on to a layer of water to immobilize them from crawling out of the tube. Sessile organisms were then counted at leisure and tufts of Pygmaea were brought home and the animals collected in an enamel pan after remaining overnight in $\mathrm{I} \frac{1}{2} \%$ formalin.

\section{The Habitats and Their Faunas}

\section{Location 2}

Shaded aspect, deep crevices between EHWN and MHWN, lower limit to middle of Chthamalus zone

A profile diagram with distribution figures for horizontal succession of animals in this type of crevice is given in Fig. 2. A description of location 2 will be given first, as this is the richest habitat with the most favourable combination of conditions for the development of the greatest number of species. It shows in a complete form a sequence represented elsewhere only partially or in fragments. Crevices here are seldom entirely dry between tides. With a northern aspect they receive maximum shade and the crevices slope down deeply, sometimes to a depth of 9-I2 in. between the slates. They are rather sheltered from wave action, and the material of the substratum, both organic and derived from weathering, will tend to stay here longest and, as shown by Glynne-Williams \& Hobart, there may be a rough grading of sediments on passing more deeply into the narrowest part of the crevice. Of ecological factors, the most significant is the absence of prolonged exposure (see Fig. I) for more than a single intertidal period. The temperature within the crevice is both low and uniform throughout tidal exposure, and relative humidity remains always at-or just below-saturation point. The food supply comes apparently from two sources, suspended particles brought to the mouth of the 


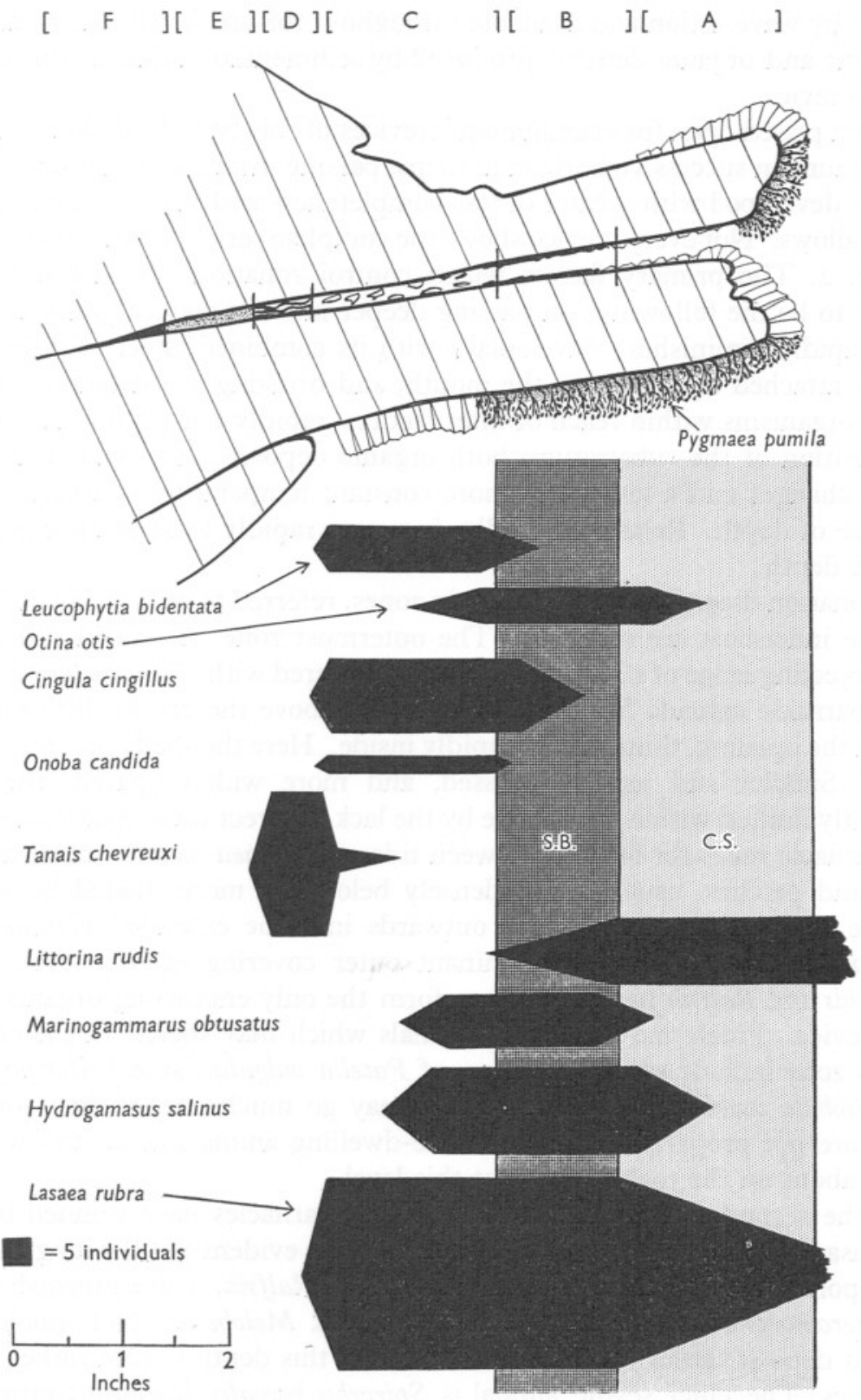

:. Diagrammatic section of a typical intertidal crevice in Dartmouth Slate at location 2. The letters refer to the successive zones within the crevice discussed in the text. Disibution diagrams are given below for the occurrence of nine of the more abundant ecies of animal within the crevice. The blacked area represents the actual number of imals taken in typical samples, apportioned between the zones, the scale being given the small black square which is equivalent to five individuals. The stippled areas icate the approximate limits of the two encrusting organisms, Chthamalus stellatus S.) and Spirorbis borealis (S.B.). 
crevice by wave action and available throughout the crevice during tidal submersion; and organic detritus produced by sedimentation on the substratum of the crevice.

When prised open for examination, crevices of this type disclose a zonation of the fauna in successive horizontal strips, passing inwards from the opening. This is developed with greater or less completeness within each crevice as the depth allows. Not every crevice shows the complete series of zones recognized in Fig. 2. The primary factors which control zonation within the crevice appear to be the following: on passing deeper into the crevice penetration of light rapidly diminishes; wave splash with its combined effect of dislodging loosely attached animals near the mouth, and bringing a constant supply of micro-organisms within reach of filter feeders, rapidly ceases; the nature and composition of the substratum, both organic deposits and weathering products, change; and a lower and more constant temperature is attained with increase of depth. Relative humidity increases rapidly to saturation point at greater depth.

A zonation diagram shows ideally six zones, referred to as $\mathrm{A}-\mathrm{F}$, all of which but the innermost are inhabited. The outermost zone (A) is constituted by the projecting ledge of slate which is closely covered with Chthamalus stellatus. This barnacle extends from its thickest layer above the crevice lip round to within the opening, thinning out rapidly inside. Here the shells become rather paler. Smaller and more depressed, and more widely spaced, they are evidently limited within the crevice by the lack of direct wave splash on which the barnacle relies for feeding between tides. Pygmaea pumila occurs also in tufts and patches, usually most densely below the more shaded lip of the crevice. The whole zone grades outwards into the extended ChthamalusPygmaea zone which is the dominant outer covering at this level. With Spirorbis and Ralfsia in zone B these form the only encrusting organisms in the crevice. Freely moving larger animals which may shelter in the crevice at this zone include small specimens of Patella vulgata, large Littorina rudis and Gibbula umbilicalis. The two latter may go much deeper than zone A. They are not properly speaking crevice-dwelling animals at all and wander freely about on the rocks outside at this level.

At the second zone of the crevice (B) the barnacles have thinned out to final disappearance, but the penetration of light is evidently still strong enough to support an encrusting film of the brown alga Ralfsia, a fine greenish scum of Enteromorpha and often an encrusting pink Melobesia. Not much permanent deposit settles here and the crevice at this depth is kept rather clean by waves. The chief sessile animal is Spirorbis borealis, forming continuous sheets or patches, where the animals are still able to filter out nutriment from particles washed in by waves. This level in the crevice is the favourite site for Otina otis, which always, unlike Leucophytia, avoids regions of thickest accumulation of detritus. It prefers to browse upon a fairly clean surface, picking up 
organic fragments, and especially diatoms lodged by the wave-splash in slight irregularities of the surface. From the splash, Spirorbis filters out nutriment of much the same kind as Otina secures with its radula. Otina by no means confines itself to this zone. It is able to venture outwards, even while the tide is out, to the projecting ledge of barnacles. Here it crawls about actively, kept moist by splash, and often ventures among the barnacles on the under side of the lip of the crevice.

A deeper zone (C), beyond the Spirorbis fringe, occurs wherever a space of about $\frac{1}{2}$ in. is still left between the roof and floor of the crevice. Small stones, pieces of shell, pebbles and coarser sand are able to lodge here. There collects also a deposit of fine clay-like weathering products, and a rich organic debris lodges in the interstices between the larger particles. The fauna is richer here. While Spirorbis is entirely lost, the chief species become Cingula cingillus, Lasaea rubra, Leucophytia bidentata, much reduced numbers of Otina otis, and many small individuals of Littorina rudis, which, however, is a good deal more common towards the mouth of the crevice. All the animals mentioned feed in various ways on the rich organic deposit. They include several species with purely marine affinities, such as Lasaea rubra, Cingula cingillus and Littorina rudis. A striking feature of the location, however, is the migration of a terrestrial element back between tide marks, into the specialized crevice locality. In smaller numbers, but usually in each crevice with one to a dozen specimens, are represented the myriapod, Scolicoplanes maritimus; the pseudoscorpion, Neobisium maritimum; a collembolan, Anurida maritima; a machilid, Petrobius maritimus; and the coleopteran, Aëpus robini; while the pulmonates Leucophytia and Otina are themselves supratidal rather than marine in affinities. In addition, the small, reddish brown marine mite, Hydrogamasus salinus, is present, often in immense numbers, forming one of the chief items of the species list. The air interlocked in small spaces at this level of the crevice is evidently sufficient to enable most of these animals to remain air-breathing between tides and to live compatibly side by side with marine members of the fauna. Some species, such as the mite and the collembolan, evidently retain air by a setose or hairy covering and are difficult to wet; but others, such as Leucophytia, are probably truly amphibious and breathe dissolved air from the sea water during high tides. Other members of the fauna in considerable numbers in zone (C) includes the amphipods Hyale nilssoni, Marinogammarus obtusatus (also found at the crevice mouth in the barnacle fringe), and frequently a specimen of the little teleost, Blennius galeritus, which regularly lodges in air-filled crevices between the tides. Among the isopods, Sphaeroma serratum, and Naesa bidentata are probably most important. Of the molluscs, another rissoid, Onoba candida, is regularly present, though in much smaller numbers than Cingula, as well as Mytilus edulis, pale brown in colour, up to $5 \mathrm{~mm}$. in length and attached by byssus threads to the rock. The worms include several eunicids and terebellids, and also Eulalia 
viridis, which is typical both here and, perhaps even more, in the Spirorbis and Chthamalus zones. The high tidal nemertean, Lineus longissimus, is very frequent; there are often five or six in each crevice.

In a narrow, but fairly constant zone at a deeper level (D) the accumulation of sand and detritus becomes thick enough for the peracaridan Tanais chevreuxi to form its system of galleries. Each occupies the whole width of a narrow zone of compacted sand, about $\mathrm{I}$ in. across at most, and the burrows form a closely branching system in general parallel with the direction of the crevice. The chief animals accompanying Tanais, crawling back into deeper recesses between lodgements of muddy sand, are the isopod Sphaeroma serratum, reduced numbers of Lasaea, the shells now pale and transparent, and Cingula and Leucophytia.

Deeper still in the crevice, in zone (E), the clay deposit, chiefly the reddish product of the weathering of slate, becomes even more compact and finer in grade, and is penetrated by few animals with the exception of the depositfeeding worms, Amphitrite gracilis and Cirratulus cirratus whose food-collecting tentacles extend outwards to the more open zones, C and D, in places where the Tanais zone is interrupted or unrepresented.

Zone $\mathrm{E}$ may extend backwards 3 or 4 in. into the crevice, after which, at the level $\mathrm{F}$, the sheer faces of the slate laminae remain in contact or separated only by a film of red or yellow clay formed by weathering action. Here no space remains for penetration by living organisms.

\section{Location 3}

Shaded aspect, deep crevices at and around splash line of MHWN, near the upper limit of the Chthamalus-Pygmaea zone

The fauna here is a good deal less rich than that just described, and there are a number of differences in the impact of the environment. The chief ecological difference is evidently that of greater temperature fluctuation (see Fig. 3). There is a higher average temperature with longer exposure between tides and much greater insolation of rock surfaces. Consequently, relative humidity is lower because of both longer evaporation and lack of waterretaining deposits. The crevices tend to be less deep, and this is probably in some measure due to the different nature of the weathering: the slates tend to be sheared off or delaminated more by subaerial erosion than by the deeper action of water. Type 3 crevices may remain dry for a total period of up to $200 \mathrm{hr}$. within a tidal cycle. This ensures that deposit feeders will find conditions unsuitable. Many of the animals of the lower fauna have dropped out. Perhaps this has as much to do with unfavourable conditions of food supply as with temperature or humidity.

Leucophytia, which was typical of deposit feeders at $\mathbf{2}$, is lost entirely. Otina is still able to do well here and nestles among the barnacles or with Lasaea. It evidently reaches here the higher limit of its intertidal range. Like the 
limpet, Otina is able to crawl about actively and forage for wave-lodged diatoms or filamentous algae which are often found in its gut; it is able to feed by means of its radula from a rather clean-swept surface. Many tufts of Pygmaea still occur at the barnacle fringe at the mouth of the crevice. They shelter vast numbers of Lasaea rubra, which, as long as Pygmaea persists, is as abundant

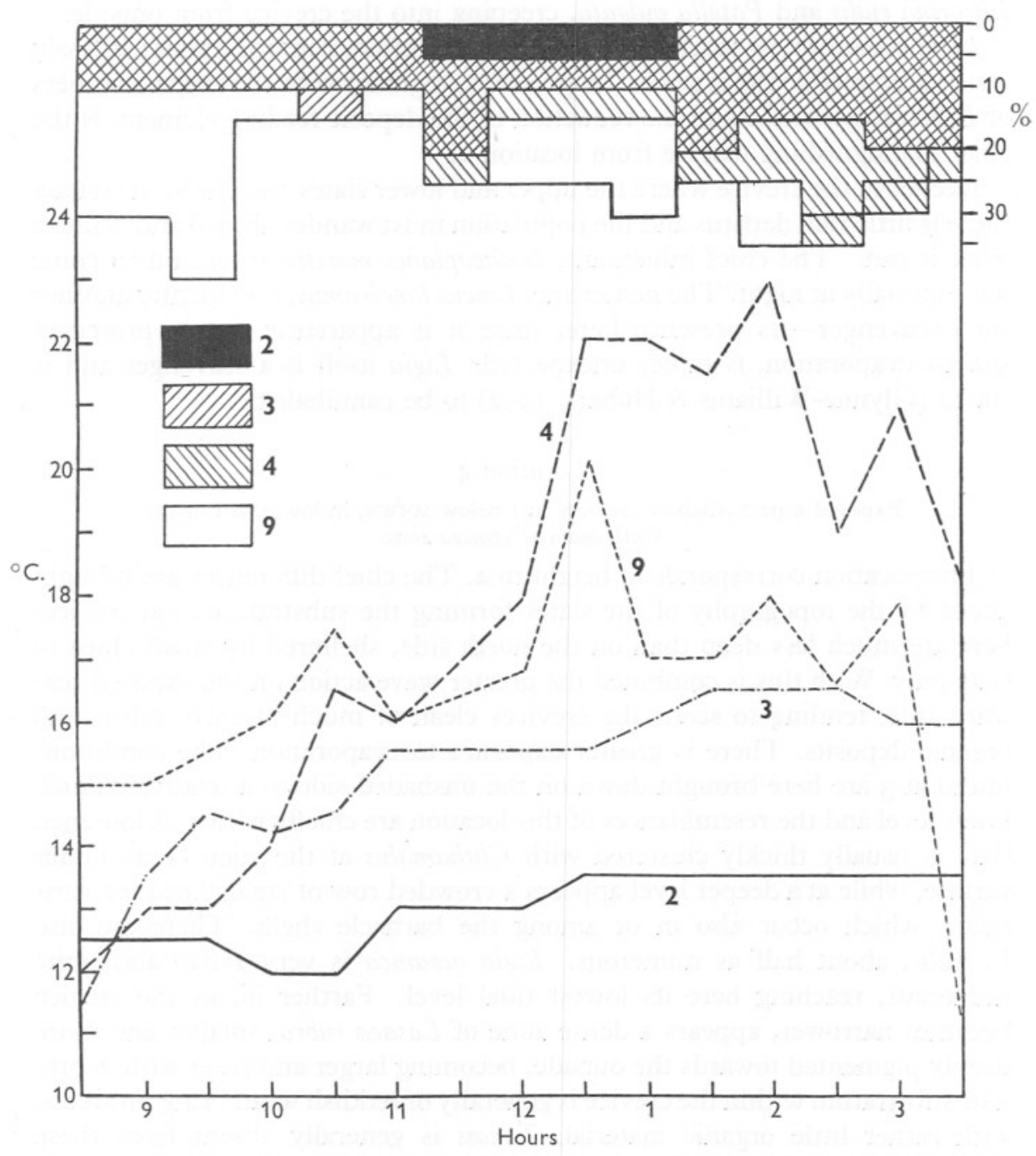

Fig. 3. Graphs showing half-hourly temperature readings over a complete intertidal period on a portion of the western reef at Wembury, on I8 June I95I; and (above) diagrams showing the percentage relative humidity by which the points selected fell short of saturation at the same intervals. Position (i), referred to in the text, was just above the bare rock surface at location $\mathbf{9}$, and the remaining three stations are at typical positions of locations 2, 3 and 4 . 
as below. Lasaea is a suspension feeder and must at higher levels have a stringent tidal periodicity imposed on its feeding and other activities. Littorina neritoides is here almost as abundant as Lasaea. It prefers to nestle in barnacle shells and also presses in dense clusters as far into the crevice as it is possible for smaller individuals to go. There are still at this level many Littorina rudis and Patella vulgata, creeping into the crevice from outside.

Ligia oceanica now reaches its densest distribution, running about restlessly inside and outside the crevice. Its presence, together with the larger numbers of Littorina neritoides and the reduction of the deposit-feeding element, is the chief distinguishing feature from location 2.

Deeper in the crevice where the upper and lower slates are almost in contact there is little rich detritus and the population must wander abroad and capture what it can. The chief inhabitant, Scolicoplanes maritimus, is said to come out especially at night. The nemertine, Lineus longissimus, is evidently another such scavenger-its presence here, since it is apparently poorly protected against evaporation, is rather unexpected. Ligia itself is a scavenger and is stated (Glynne-Williams \& Hobart, I952) to be cannibalistic.

\section{Location 4}

Exposed aspect, shallow crevices just below MHWN, in lower half of the Chthamalus-Pygmaea zone

This location corresponds in height to 2. The chief differences are brought about by the topography of the slates forming the substratum; the crevices here are much less deep than on the north side, sheltered by small chips of slate only. With this is combined the greater wave action on the exposed seaward side, tending to scour the crevices clean of much of their debris and organic deposits. There is greater exposure to evaporation. The conditions found at 3 are here brought down on the unshaded side to a relatively much lower level and the resemblances of this location are chiefly with 3 . A loosened slate is usually thickly clustered with Chthamalus at the edge of its under surface, while at a deeper level appears a crowded row of small Littorina neritoides, which occur also in or among the barnacle shells. There are also L. rudis, about half as numerous. Ligia oceanica is very active and quite numerous, reaching here its lowest tidal level. Farther in, as the crevice becomes narrower, appears a dense zone of Lasaea rubra, smaller and more deeply pigmented towards the outside, becoming larger and paler with depth. The substratum within the crevice is generally of reddish weathering products, with rather little organic material. Tanais is generally absent from these crevices which are scarcely deep enough, nor with sufficient supply of building material, to enable it to construct its burrows. Occasionally a small patch of mud may support a dozen or so Tanais and here conditions are often sedimented enough for Cingula which-with or without Tanais-may continue quite abundant. Leucophytia is present in these patches, but reduced both in 
size and number; on the unsheltered side this is about the upper limit of its extent. Otina, on the other hand, being less tied to thick deposits and doing better on cleaner ground, seems to tolerate these crevices quite well, often sheltering in empty barnacle shells. The local humidity at such points must closely approach saturation, although in general it may fall a good deal lower at 4 (Fig. 3). The carnivores or scavengers, Machilis and Aëpus, are represented here, but more poorly than at 2. Anurida maritima often swarms. Of the mites Hydrogamasus does not often turn up here, but the large reddish Bdella and Cyrthydrolaelaps are usually abundant, creeping out upon the heated rock surface over the barnacles.

\section{Location 5}

Exposed aspect, shallow crevices at splash line of MHWN, near upper limit of Chthamalus-Pygmaea zone, same level as 3

This zone is most readily comparable with 3 , but with the unshaded conditions of south exposure, the environment is a good deal more harsh. In many ways the fauna approaches that of 6 . The crevice is mainly filled with clean, pinkish brown weathering products along the joint plane of the slates, and little life exists in such places. At the outer part of the crevice, however, a fringe of Pygmaea helps to accumulate a small amount of organic deposits and provides shade for a narrow zone of Lasaea rubra and Littorina neritoides occurring within the mouth of the crevice. These are the two dominant animals. Lasaea is near the top of its range at this point and Littorina neritoides near its optimum. Both yielded over 200 individuals in the area sampled. L. rudis accompanies $L$. neritoides but is of small size and much less abundant. Ligia oceanica wanders about actively and specimens of the Geranomya larva were found which had probably strayed from the Pygmaea zone. Scolicoplanes maritimus was at times found here, but conditions seemed too dry for Anurida maritima. There are no Tanais and no worms. Deposit feeders are at a great disadvantage and the chief nutriment available consists of suspended particles borne by the waves.

\section{Locations 6 and 7}

6, exposed aspect, shallow crevices in the zone of black lichen, Verrucaria maura, above the barnacle zone, at $\mathrm{I}$ 7-I9 ft. C.D. 7, exposed or sheltered aspect, cracks in the rock never reached by the tide, in the zone of yellow lichen, Xanthoria, I9-2I ft. C.D.

These were the highest points sampled, and both were usually taken on the unshaded side of the profile. Conditions tend to be increasingly harsh and the fauna greatly impoverished. At 6 , although there are no barnacles exposed on the surface, Chthamalus may exist in one or two sparse clusters in the crevices. Pelvetia canaliculata may still be growing at the surface, and its thallus and holdfasts provide shelter for a few animals (Colman, I940). In the crevices Littorina neritoides is now by far the dominant organism, in 
practically terrestrial conditions reached only by the splash of high-water springs. L. rudis is still present but much more scarce. Ligia oceanica is active and plentiful, but none of the mites appear to persist. Lasaea rubra just reaches crevice 6 though it is outstripped in numbers by Littorina neritoides; its presence here is a remarkable achievement for a lamellibranch relying on suspension-feeding.

Finally, at 7, small L. neritoides almost alone persists in an environment that is perfectly terrestrial. Occasionally small specimens of $L$. rudis make an appearance. There is little detritus or wave-lodged material; temperature extremes and lack of shade are very great; insolation is prolonged and high, and humidity very low. Ligia has practically disappeared and we find in its place small numbers of a slower terrestrial oniscid.

\section{Location 8}

In tufts of the lichen Pygmaea pumila, on the unshaded rock surface in the zone of Chthamalus-Pygmaea, at II-I4 ft. C.D. (cf. Colman, I940).

Tufts of this lichen have remarkable water-retaining power and provide almost the only cover on the surface of bare rock for an extension of the faunas normally sheltering in crevices. The faunas of Pygmaea tufts were discussed by Colman (1940). The chief differences to be noted from crevice 4 are the smaller number of actual crevice-dwelling species to be found among Pygmaea, and the extraordinary abundance of two species, Lasaea rubra and the isopod Campecopea hirsuta. Colman remarks on the teeming masses of Lasaea, the highest number recorded by him being I2,I40 in a sample of Ioog. of damp lichen. A comparable order of density for $15 \mathrm{~cm} .{ }^{2}$ of Pygmaeacovered surface was obtained during this survey, a typical figure being 898 . Campecopea hirsuta is present here in numbers far greater than at $\mathbf{2}$ and $\mathbf{4}$ where it was also seen. Colman's figures of 2204 and 3772 per Ioog. of lichen are of similar order to the sample of 494 for one square recorded in this survey. Of the acarines found here, not named by Colman, the red mite Bdella appears to be the most numerous. Of other migrants from the crevices, Littorina neritoides, L. rudis, Anurida maritima and Petrobium maritimum figure prominently. A new arrival is the tipulid dipteran Geranomya unicolor, of which large numbers of larvae were always found. This insect gave a remarkable demonstration of osmotic regulation in its resistance to a $5 \%$ solution of formalin in which it remained alive in immersed tufts of lichen overnight.

\section{Locations 9 and ro}

9, bare rock surface on unshaded side, between EHMN and MHWN near the lower level of the Chthamalus-Pygmaea zone. ro, bare rock surface on unshaded side above MHWN near the upper limit of the Chthamalus-Pygmaea zone.

These locations are among the least favourable of all, and very few of the animals present in crevices at $\mathbf{4}$ and $\mathbf{5}$ are able to venture out here. The fauna 
is denuded of practically all species except tiny specimens of Littorina neritoides and L. rudis, which nestle in empty barnacle shells and are evidently able to crawl about at night and in conditions of greater shade. At 9 L. rudis is far predominant; at ro it is reduced in numbers and $L$. neritoides has well overtaken it, being present in samples of more than 400 to a $15 \mathrm{~cm} .{ }^{2}$ patch. Lasaea rubra has totally disappeared on the open surface. Evidently the evaporation rate is too great even with the tight closing of the shell during the withdrawal of the tide. Of the scavengers, Ligia probably comes out by night, as may also Scolicoplanes, but in the daytime Bdella alone remains swarming over the open rock surface in ceaseless activity.

\section{Location I}

Crevices at upper limit of Fucus serratus-Laurencia pinnatifida zone, ro ft. C.D., and below, shaded by damp thallose algae.

The fauna of crevices of this type presents a strong contrast with all of the locations higher up. The barnacles of the outer lip of the crevice are lacking, tending to be replaced by portions of the carpet of Laurencia, which creeps in slightly around the mouth of the crevice though never quite removed from the light. There follows inside the entrance to the crevice a rather narrow zone, which is often silted up, or-in cleaner conditions-supports a growth of encrusting red algae and bryozoa. Ralfsia never occurs here and there is usually too much silt for Spirorbis, which drops out almost entirely from the crevice fauna in most cases, but is still able to settle in abundance at this level on clean blades of Fucus. In this part of the crevice and farther in, on the organic deposits, Lasaea rubra still flourishes. Specimens are of large size and pale colour (Fig. 4). Leucophytia bidentata does well too, sometimes on very thick yellow-brown silt. Cingula is decidedly less common and Otina quite lacking. Sphaeroma is much less seen, the chief isopods being Naesa bidentata $(=$ Dynamene spp.). There appear to be few Tanais in any crevices of this type. Entrants into the fauna which are never seen higher up are a small Amphiura, a pilumnid crab, Anomia ephippium of small size, and the very distinctive half-crab Porcellana platycheles. Tiny Mytilus edulis also appear, being sometimes also seen higher up at 2. Most of the insects seem to be able to extend down to this zone where the crevice is open and clean enough to allow them, but the accumulation of moist silt is probably their limiting factor. Aëpus is on the whole less abundant than at 2, but a new arrival is the heteropteran Aëpophilus bonnairei which is never present higher up and is distinctly a low-tidal form. With it occurs the bright green-bodied juvenile stage of the ectoparasitic isopod Gnathia oxyuraea.

The deeper part of the crevice is often permanently filled with waterlogged, but fairly stiff, sand and detritus. The most typical new entrant here is the burrowing lamellibranch Hiatella arctica, which forms horizontal galleries in the mud communicating by its red siphons with the outer part of 
the crevice. It is never found farther up, and with Porcellana, Gnathia and Aëpophilus forms a group of species diagnostic of this type of habitat. Among the worms present in the substratum Perinereis marioni, and Eulalia viridis are as common as above, accompanied by Amphitrite gracilis and Cirratulus cirratus, and-especially where there is much clay-Phascolosoma minutum. Groups of sabellariid tubes are common on the cleaner parts of the rock.

\section{The ENvironment}

The moisture content and the proportion of organic detritus present in the substratum of the crevice have been quantitatively assessed and discussed by Glynne-Williams \& Hobart (1952). During the present work the two factors of relative humidity and temperature within selected crevices have been measured for a typical summer day. The temperature was recorded at each of four selected points on the outcrop of the west reef illustrated in Fig. I, at half-hourly intervals during a complete period of intertidal exposure on I8 June I95I. This was selected as an average warm day on which conditions of temperature and evaporation approached their higher extreme. The meteorological conditions for Plymouth for the day included 'Sunshine Ir. $6 \mathrm{hr}$., Max. Temperature (in shade) $62^{\circ} \mathrm{F}$, Sea Temperature $58.5^{\circ} \mathrm{F}$, Barometer $30.08^{\prime}$.

The first series of temperature readings was taken at position (i), in air, $\mathrm{I} \mathrm{cm}$. from the exposed rock surface, on the unshaded south aspect corresponding to location 9. A second series of readings was recorded from within a crevice of type 4 on the unshaded side. On the shaded north side, observations of temperature were made at the bottom of a crevice of type 2, and higher up at the bottom of a crevice of type 3. Temperatures were recorded by Cambridge Instrument Company thermocouples, with a narrow flexible thermometer antenna which could be thrust into the full depth of a crevice, with care to avoid contact with the rock surface and without dislodgement of the slate or opening up of the surroundings. The results are presented in the lower half of Fig. 3. The internal temperature of crevice 2 remained low and uniform, rising by $0.5^{\circ} \mathrm{C}$ at II.0o hr. to continue through the afternoon at its highest value of $13.5^{\circ} \mathrm{C}$. In crevice 3 (where the intertidal exposure was longer) the temperature had risen at $09.30 \mathrm{hr}$. to $14 \cdot 5^{\circ} \mathrm{C}$, continuing, though less steadily, at an average of $2^{\circ}$ higher than in crevice 2 . On the exposed rock face at position (i), the temperature had risen to $15^{\circ}$ within $30 \mathrm{~min}$. after the tide had ebbed from that point, and, with a recession during the morning due to a light shower of rain, continued to rise throughout the morning to reach its peak of $20^{\circ} \mathrm{C}$ at I2.30 hr. In the crevice of type 4 the temperature, beginning at the same level as in crevices $\mathbf{2}$ and $\mathbf{3}$, rose rapidly during the early part of the morning till it exceeded at II.oohr. that of the exposed rock surface (i). This was apparently to be explained by the rapid heating up of the unshaded rock mass surrounding the crevice and the absence of the cooling 
effect of breezes and air currents that came into play throughout the day upon the exposed surface. The temperature in this crevice reached a peak of $24^{\circ} \mathrm{C}$ at $\mathrm{I} 4.00 \mathrm{hr}$. and continued during the afternoon higher than, but with as great fluctuations as, that of (i).

Half-hourly measurements of relative humidity were made simultaneously with temperature readings at the same points by exposing small squares of cobalt thiocyanate paper, which was kindly supplied by Dr M. E. Solomon of the Pest Infestation Laboratory, D.S.I.R., Slough. Standardizing was carried out by exposure in desiccators in atmospheres of known relative humidity over solutions of potassium hydroxide of increasing specific gravity after the method of Buxton \& Mellanby (1934). The colour standards so obtained were then compared with the reading of Edney paper hygrometers, and were regarded as having an accuracy of within $5 \%$. Squares of humidity paper of $\frac{1}{2} \mathrm{~cm}$. were introduced into crevices within the end of glass rods inserted into the crevices with care to avoid moisture condensed upon the rocky surface, and the papers, removed after $30 \mathrm{~min}$. exposure, were placed in tubes of liquid paraffin for comparison in the laboratory.

The readings of relative humidity at (i) (location 9) and locations 2,3 and 4 are presented on the upper portion of Fig. 3. Crevice 2 maintained much the highest relative humidity throughout the intertidal period, falling to $95 \%$ between the hours of II.30 and I3.00, and remaining the rest of the time at saturation. The lower extreme is represented by the exposed rock surface at point (i) where the relative humidity fluctuated throughout the day, frequently falling to $65 \%$. Intermediate values were obtained for crevices of type 3 , which did not exceed $90 \%$ during the intertidal period and fell to $80 \%$ at II. $30 \mathrm{hr}$. and later during the afternoon. The type 4 crevice maintained a relative humidity similar to 3 during the early part of the day, later falling rapidly with rise in air temperature.

It would be an over-simplification to emphasize too strongly the apparently close correspondence between the peaks of temperature and the points of greatest saturation deficit. Obviously the variations of relative humidity form an ecological factor with very complex underlying causes. The water content of enclosed air may vary locally under the direct influence of the temperature of the atmosphere and of the substratum, together with variations in the amount of shade and exposure, and drainage of the crevice substratum (these two factors being dependent on the detailed topography of the ground); the percentage of intertidal exposure; the amount of wave-splash and the incidence of local breezes.

On the profile diagram (Fig. I) have been superimposed curves for two sets of factors established by Colman (1932) with application to intertidal zonation at Wembury. The two lower curves are generalized compound curves showing the average percentage of exposure, for actual tidal level and for the splash level $2 \mathrm{ft}$. higher, during a complete tidal cycle. Such a curve is 'built up of 
(I) the semi-diurnal tide curve and (2) the curves, having a wave-length of a fortnight, formed by the height of high and low waters as they vary between one set of springs and the next'. The upper curve represents 'the length of time during which any given level may be continuously dry during one fortnight (Vernal Equinox)'.

The last curve is applicable to an area lying above EHWNT, below which no place is continuously exposed during the whole of any tidal period. Referring to the upper limits of the ranges recorded in Fig. I, it will be noticed that Spirorbis borealis reaches the splash zone of EHWNT; this species is one that appears to need daily, even at the lowest high neap tides, some amount of wave-splash and access to food. Chthamalus stellatus extends well above this

\section{Table II. Percentages of Exposure, and Maximum Number of Hours of Exposure at Upper Limit, For SOME Crevice-DWelling ANimals}

\begin{tabular}{|c|c|c|c|}
\hline \multirow[b]{2}{*}{ Species } & \multicolumn{2}{|c|}{$\begin{array}{l}\text { Average } \% \text { of daily exposure } \\
\text { (splash figures in brackets) }\end{array}$} & \multirow{2}{*}{$\begin{array}{c}\text { Maximum } \\
\text { number of } \\
\text { hours exposed } \\
\text { (upper limit) }\end{array}$} \\
\hline & Upper limit & Lower limit & \\
\hline Ligia oceanica & IOO (IOO) & $57(48)$ & Never submerged \\
\hline Chthamalus stellatus & $98(90)$ & $52(45)$ & 325 \\
\hline $\begin{array}{l}\text { Tanais cavolinii } \\
\text { Hydrogamasus salinus }\end{array}$ & $85(66)$ & & 165 \\
\hline $\begin{array}{l}\text { Hydrogamasus salinus } \\
\text { Spirorbis borealis }\end{array}$ & $86(70)$ & 太 & I85 \\
\hline $\begin{array}{l}\text { Spirorbis borealis } \\
\text { Lasaea rubra }\end{array}$ & $\begin{array}{r}86(70) \\
100(95)\end{array}$ & $\begin{array}{c}\star \\
\star\end{array}$ & $\begin{array}{l}18 \\
37\end{array}$ \\
\hline Cingula cingillus & $93(83)$ & $\star$ & 250 \\
\hline Littorina neritoides & $100(100)$ & $82(64)$ & Never submerged \\
\hline L. rudis & 100 (I00) & $60(50)$ & Never submerged \\
\hline Leucophytia bidentata & $93(65)$ & & 165 \\
\hline Otina otis & $93(78)$ & $60(49)$ & 230 \\
\hline
\end{tabular}

level to MHwst. During neap tides it may remain out of the high-water splash zone at its upper limit, as may also Lasaea rubra. For the greater portion of a fortnightly tidal cycle, Ligia oceanica and Littorina neritoides appear to be quite independent of wetting by splash. For some of the animals whose vertical distributions are recorded in Fig. I, we may extract Table II, expressing the average percentages of daily exposure at their upper and lower limits, and also the total number of hours during which these species-at the upper limit of their range-may remain continuously exposed during a fortnightly tidal cycle.

\section{Distribution OF THE FaUnA}

A species list for the habitats of the upper intertidal zone at Wembury is given in Table III. It has not been attempted to give actual numbers of single counts at particular crevices sampled, but rather to record conditions of density, from dominance to occasional presence. In the distribution diagrams (Fig. 6), quantitative data have been expressed by the scale of density shown on the figure. Each estimate is again not the result of any single sample, but 
gives a generalized picture from the results of two seasons' records from a large number of stations. Twenty-two species of animals are dealt with, the distributions being grouped according to taxonomic relationships, to give a comparative picture of the ecology of fairly closely related types of animals. In many cases, it will be realized that a uniform distribution of a species over the area of $10 \mathrm{~cm}^{2}$ sampled is not implied. Thus, with Lasaea, individuals will frequently be crowded together in a narrow row a centimetre wide, and the remaining drier parts of the sampled square may show few or no specimens. An even distribution is much more a feature of crevices at $\mathbf{I}$ and 2. At 3,4 and 5 , the greater part of a crevice may be too dry to be inhabited, and this, rather than lower density at points of actual occurrence, accounts for the diminishing numbers of several of the species at these locations.

Some observations in more detail on the ecology of several groups of species of special importance in upper tidal crevices may be presented here. GlynneWilliams \& Hobart (I952) have already recorded much useful data, especially about the terrestrial element in the fauna, in relation to feeding habits and position in the crevice.

\section{Isopoda}

The principal isopods are five in number, Ligia oceanica, an unnamed terrestrial oniscid of the wood-louse type, Campecopea hirsuta, Sphaeroma serratum and Naesa bidentata. Of these we may neglect the oniscid species which is of chief interest in showing the close approach to terrestrial conditions at 7. Ligia is typical of the upper half of the profile, most abundant at 3 , next at 4 , wandering about actively outside the crevice, especially at night. Its upper limit is probably governed by the dryness and shallowness of the crevice and the lack of adequate food supplies. It is thus almost absent at 7 and is in no sense truly terrestrial. It likewise appears to avoid Pygmaea (Colman, I940) and is markedly reduced in numbers at $\mathbf{2}$ and quite absent at I. Nicholls (I93I $a, b)$ gives some account of its ecology and feeding, and this aspect has also been studied by Glynne-Williams \& Hobart (1952). Ligia is replaced at 2, and also accompanied at 3 , by the much more sluggish isopod Sphaeroma serratum. This species is far less tolerant of drying-out or temperature fluctuations. It is limited above at the MHws line, and at its lower range just reaches $\mathbf{r}$. Naesa bidentata is found together with Sphaeroma in 2, but both these isopods are much more typical of deeply silted crevices and they extend downwards to reach their greatest abundance, in the area studied, at $\mathbf{I}$. They are found very little if at all on the unshaded south side. Numerically, by far the most important isopod is the small Campecopea hirsuta. As found by Colman (1940) in his sample from Pygmaea, this species is present in teeming numbers at $\mathbf{8}$, and there are always a few individuals represented at 2 and at 4 where they are likely to be overlooked on account of small size. 


\section{Table III. Species List from Intertidal Crevices and Related Habitats}

Lineus longissimus (Gunnerus)

Small pink nemertine (indet.)

Perinereis marioni (Aud. and Edw.) $\mathrm{O}$

Unidentified eunicids

Eulalia viridis (O. F. Müller)

Harmothoë imbricata L.

Cirratulus cirratus (O. F. Müller)

Amphitrite gracilis Grube

Spirorbis borealis (Daudin)

Phascolosoma minutum Keferstein

Chthamalus stellatus (Poli)

Tanais chevreuxi Milne-Edwards

Sphaeroma serratum (Fabr.)

Naesa bidentata (Adams)

Campecopea hirsuta (Mont.)

Ligia oceanica L.

Unidentified terrestrial oniscid

Gnathia oxyuraea (Lillj.)

Hyale nilssoni (Rathke)

Marinogammarus obtusatus (Dahl)

Porcellana platycheles (Pennant)

Juvenile pilumnid crab

Anurida maritima (Guérin)

Petrobius maritimus Leach

Aëpophilus bonnairei (Sig.)

Micralymma marinum (Stroem.)

Aëpus robini (Laboulb.)

Unidentified caddis

Geranomya unicolor

Scolicoplanes maritimus (Leach)

Neobisium maritimum

Cyrthydrolaelaps hirsutus Berlesé.

Hydrogamasus salinus Laboulbene

Bdella interrupta Evans

Protereupetes sp.

Anomia ephippium L.

Mytilus edulis L. (juv.)

Lasaea rubra (Montagu)

Hiatella arctica (L.)

Tapes pullastra

Acanthochitona crinitus (Pennant)

Littorina neritoides (L.)

L. rudis (Maton)

L. littoralis (L.)

Gibbula umbilicalis (da Costa)

Cingula cingillus (Montagu)

C. cingillus var. rupestris

C. semistriata (Montagu)

Onoba candida (Brown)

Onchidella celtica (Cuvier)

Otina otis (Turton)

Leucophytia bidentata (Montagu)

Blennius galeritus $\mathrm{L}$.

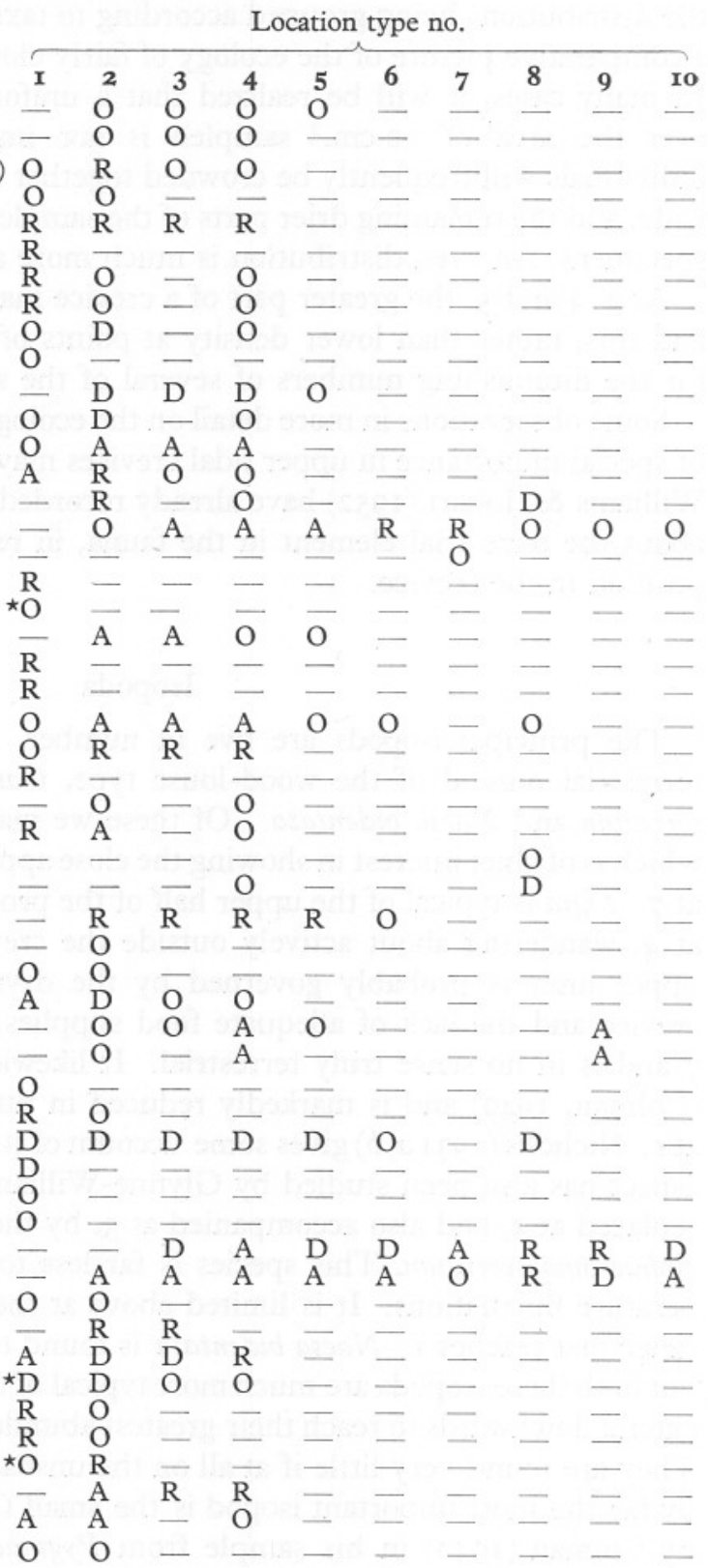

$\mathrm{D}$, dominant; A, abundant; $\mathrm{R}$, regularly present; $\mathrm{O}$, occasionally present; -, absent.

* Occurs at Whitsands but not seen at Wembury.

Nomenclature as in Plymouth Marine Fauna (Marine Biological Association, I93I). 


\section{Tanais chevreuxi}

In choice of site, both with respect to tidal height and to depth in the crevice, this is one of the most restricted animals encountered in the present study. Its requirements appear to be a sandy mud, richly silted by weathering products and organic detritus, with an admixture of sufficient coarse sand to enable its galleries to be given a compact structure. As described above (p. I96) it presses deeply into crevices to a point where there is room for one layer only of animals between the two slates. Its appearance is an indicator of fairly mature conditions of succession in locations of type 2. The only other place where it is at all abundant is sometimes at 4 . It never appears at 3 , where its absence is one of the criteria of this type of crevice, and it apparently becomes cut out at $\mathbf{I}$ where the conditions of silting up and waterlogging of the crevice are too extreme. Dennell (I937) has described the feeding habits and ecology of Apseudes talpa, and this is the species of tanaidacean found by Glynne-Williams \& Hobart at Anglesey. It would be interesting to know something more about the distribution and ecological requirements of Tanais chevreuxi, and to compare its occurrence at Wembury with that of the allied species, $T$. cavolinii, which would seem not to occur in crevices.

\section{Mites}

These may be taken together as a group, though they are by no means without clear-cut ecological distinctions, as between the species mentioned at Wembury. On the shaded side, in greatest concentration at $\mathbf{2}$ and extending abundantly down to $\mathbf{I}$, the chief mite is Hydrogamasus salinus, small in size and polished tan-brown. It is accompanied by a species of Protereupetes. On the south exposed side, most at home at $\mathbf{4}$ and $\mathbf{5}$ and wandering on to bare rock at 9, though found also on the shaded side, are two larger and more spectacular mites, the bright red Bdella interrupta and Cyrthydrolaelaps hirsutus. These are able to extend well up the shore into terrestrial conditions. They are airbreathing, evidently able to retain atmospheric air imprisoned between their fine setae. They appear to be widely foraging scavengers and also some of the chief carnivores of this area of the reef. The present writer has no direct observations on their feeding, but reference should be made to GlynneWilliams \& Hobart (I952), and to previous observations quoted by them.

\section{Lasaea rubra}

This little lamellibranch is the most numerous animal in the upper shore. Its astonishing abundance at location $\mathbf{8}$, in tufts of Pygmaea, has already been remarked upon by Colman. It is no less dominant at $\mathbf{1}, \mathbf{2}, \mathbf{3}$ and $\mathbf{4}$, where it crowds closely into the tighter parts of the crevices almost as thickly as it is possible to aggregate. As found by Colman, numerical differences between successive samples of such large numbers may be very great, and on the 
distribution diagrams (Fig. 6) its fluctuations do not show up, as wherever it occurs it may be expected to exceed $200-300$ in the $2 \times 15 \mathrm{~cm} .{ }^{2}$ area sampled. It seldom if ever occurs uniformly over the whole of such a patch, except at 2 and $\mathbf{I}$, where larger-sized individuals may be more evenly spaced out. At 3 and 4 its most typical occurrence is in a mass of smaller individuals pressed close together in a narrow line at the shallowest and innermost portion of the crevice. Figures for three of a number of samples taken were, for example, at a crevice of type $\mathbf{2}, 865$, at $\mathbf{8 , 8 9 8}$, at $\mathbf{5}, 455$, and most samples at I and 4 totalled well over 400 . The distribution of Lasaea is terminated abruptly by its complete disappearance above the level of 6 ; and unlike the Littorinas it is more or less coincident in its upper level with the barnacle zone, but even here it needs more shelter-which is evidenced by the presence of not a single specimen on the open surface at 9 and ro. It does best where it can take shelter by pressing into the smallest cracks or into empty Chthamalus shells, but it goes down well below the Chthamalus level, as may be seen from the present results at I, and from Glynne-Williams \& Hobart. Colman (I940), in his account of the fauna of the holdfasts of the larger brown algae (Ascophyllum, the fucoids and Laminaria digitata), finds no abundance of Lasaea, as in Pygmaea tufts. Though this bivalve is plentiful in crevices of type $\mathbf{r}$, below the Chthamalus zone, its maximum numbers always appear to occur in the neighbourhood of Chthamalus and Pygmaea.

There is a rather marked differentiation between Lasaea from two different groups of habitats. In the well sheltered conditions at $\mathbf{I}$ and $\mathbf{2}$ and the deeper parts of crevices at 3 , the average size is much larger, length of shell up to $3 \mathrm{~mm}$. or more and the colour pale. At 4,5 and 6 , and especially in tufts of Pygmaea at $\mathbf{8}$, the mean length is smaller. There is a larger element of tiny individuals below $\mathrm{I} \mathrm{mm}$. in length and the predominant group is of $\mathrm{I} \frac{1}{2}-2 \mathrm{~mm}$. (Fig. 4). The shells are all much darker brown or reddish purple in colour.

Lasaea rubra anchors itself in a confined space by a tiny byssus, and it appears to show the same thigmotactic behaviour as Otina. It is probably claustrophilic for the same reason as Otina, both tending to remain aggregated in chinks and small cavities with the greatest local humidity. It appears to be entirely a suspension feeder; even in the richest organic deposits at 2 and at $\mathbf{I}$, it appears to have no particular modifications for sucking-up detritus in the manner of a deposit feeder. At $\mathbf{6}$ and at $\mathbf{5}$ it may undergo a total dry period for at times as long as $300 \mathrm{hr}$. continuously. Here the amount of nutritive deposits must be exceedingly small, and Lasaea must have become highly efficient at capturing the suspended particles splashed up to it by wave action in its relatively short period of contact with the water. Popham (I940) has given a detailed account of the pallial cavity of this bivalve. In addition, many questions still present themselves with respect to the physiology and cycles of activity in Lasaea. At its upper limits this lamellibranch must show 


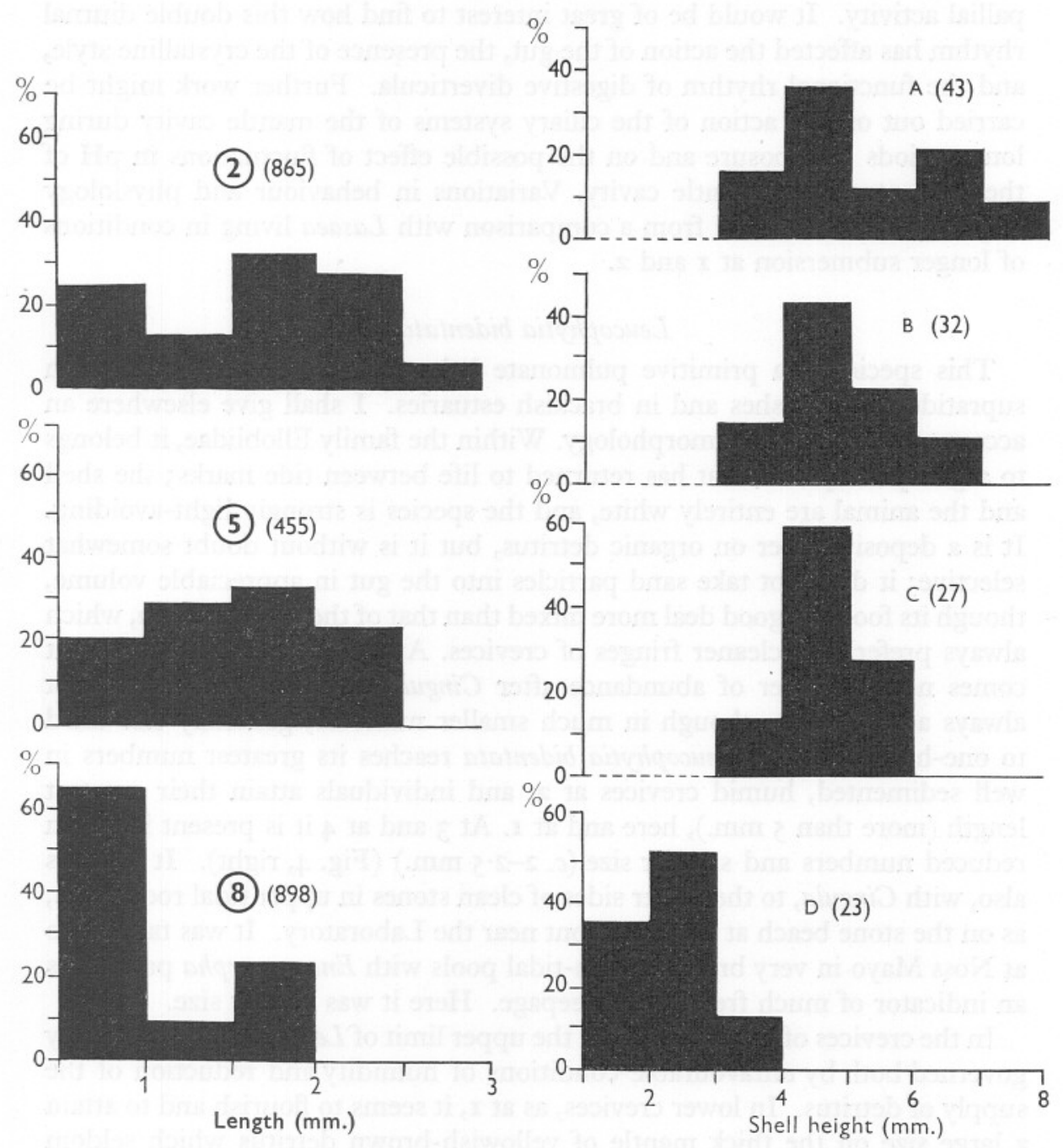

Fig. 4. Left. Histograms showing the percentage distribution of five size-groups of Lasaea rubra, in typical samples from locations of types $\mathbf{2}, \mathbf{5}$ and $\mathbf{8}$ (actual numbers in samples are bracketed). Right. Histograms showing the size composition of four samples of Leucophytia bidentata (actual numbers are bracketed). A, B and C are from deep shaded crevices of type $\mathbf{2}$ at Wembury. Individuals below $3 \mathrm{~mm}$ in height were not measured for Wembury; repeated observations at $\mathbf{I}$ and $\mathbf{2}$ indicated that they form only a minor fraction of the population. Sample D is from shallow crevices in limestone conglomerate on the wave-exposed Hoe front. The level sampled was at the lower limit of the Chthamalus zone. 
a tidal periodicity very strongly impressed on the whole of its feeding and pallial activity. It would be of great interest to find how this double diurnal rhythm has affected the action of the gut, the presence of the crystalline style, and the functional rhythm of digestive diverticula. Further work might be carried out on the action of the ciliary systems of the mantle cavity during long periods of exposure and on the possible effect of fluctuations in $\mathrm{pH}$ of the contents of the mantle cavity. Variations in behaviour and physiology might then be examined from a comparison with Lasaea living in conditions of longer submersion at $\mathbf{I}$ and $\mathbf{2}$.

\section{Leucophytia bidentata}

This species is a primitive pulmonate belonging to a family centred in supratidal salt marshes and in brackish estuaries. I shall give elsewhere an account of its functional morphology. Within the family Ellobiidae, it belongs to a group of species that has returned to life between tide marks; the shell and the animal are entirely white, and the species is strongly light-avoiding. It is a deposit feeder on organic detritus, but it is without doubt somewhat selective; it does not take sand particles into the gut in appreciable volume, though its food is a good deal more mixed than that of the related Otina, which always prefers the cleaner fringes of crevices. Among the gastropods at 3 it comes next in order of abundance after Cingula cingillus, which it almost always accompanies, though in much smaller numbers, generally one-third to one-half as many. Leucophytia bidentata reaches its greatest numbers in well sedimented, humid crevices at $\mathbf{2}$, and individuals attain their greatest length (more than $5 \mathrm{~mm}$.), here and at $\mathbf{r}$. At 3 and at 4 it is present in much reduced numbers and smaller size (c. $2-2.5 \mathrm{~mm}$.) (Fig. 4 , right). It spreads also, with Cingula, to the under sides of clean stones in upper tidal rock pools, as on the stone beach at the Hoe front near the Laboratory. It was taken also at Noss Mayo in very brackish high-tidal pools with Enteromorpha present as an indicator of much fresh water seepage. Here it was of tiny size.

In the crevices of the area studied the upper limit of Leucophytia is evidently governed both by unfavourable conditions of humidity and reduction of the supply of detritus. In lower crevices, as at $\mathbf{r}$, it seems to flourish and to attain a large size on the thick mantle of yellowish-brown detritus which seldom dries out at low tide. Glynne-Williams \& Hobart also reported it as a lowtidal crevice animal at Anglesey. It is undoubtedly very much better able to withstand submersion than Otina, and evidently employs the supra-anal lobe of its pallial skirt in respiration. The 'pulmonary' pallial cavity was never found to be filled with water. Unlike Otina, Leucophytia has no preference for wave splash or well oxygenated water; it crawls feebly, and has no power to resist the dislodging action of water movements. Specimens survived for several weeks in the still water of a tidal tank with no other aeration than a twice-daily exposure to the atmosphere. 
Otina otis

This interesting little mollusc is also a representative of the most primitive of the marine pulmonates. Its distribution on British coasts appears to be limited to the west and south-west, and Glynne-Williams \& Hobart do not record it from Anglesey. Its British and west European distribution is to be discussed elsewhere. At Wembury it is one of the most discriminating animals in its choice of environment. It is almost entirely confined to crevices and their immediate neighbourhood, within a rather short tidal range. At its

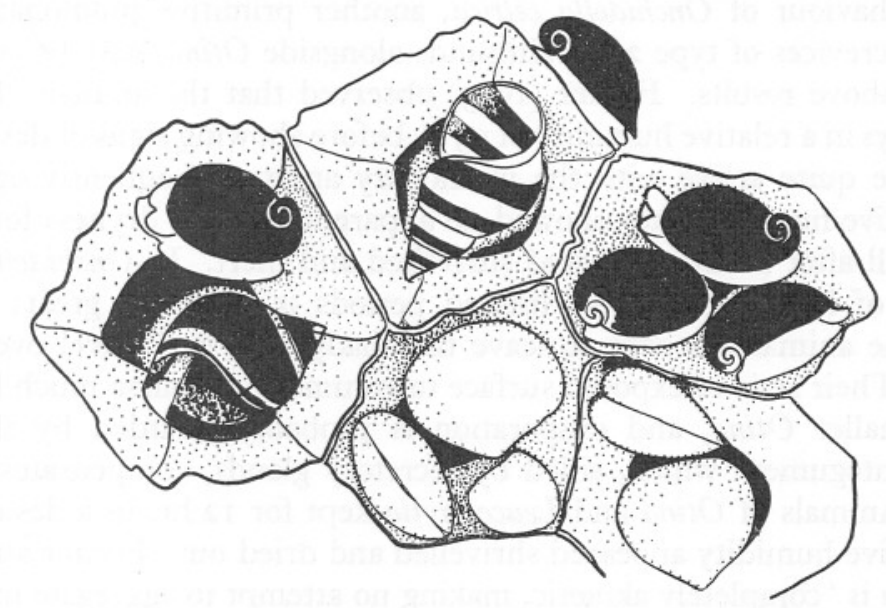

Fig. 5. A group of dead Chthamalus stellatus shells removed from within the lip of a crevice of type 4, and viewed from underneath to show the occurrence within them of Otina otis and Littorina neritoides (black), Cingula cingillus (banded) and Lasaea rubra (white).

maximum occurrence at $\mathbf{2}$ it avoids the more heavily silted conditions in the deeper parts of the crevice, and creeps out upon the Spirorbis-Ralfsia zone, though it often intermingles with Leucophytia farther in. A favourite habit is to creep farther out on to the barnacle fringe in shaded spots, and to nestle in empty Chthamalus shells like Littorina neritoides (Fig. 5). It is above all a lover of clean conditions, and is never found in situations where excess detritus is present. Of all the molluscs, save the littorines, it has the highest lower limit, and it does not accompany Leucophytia down to the silted conditions at $\mathbf{I}$. It is best developed at $\mathbf{2}$, but unlike Leucophytia it can live favourably at 3 and it is present in greater numbers than Leucophytia at 4. Its mode of life is not unlike that of a limpet; with its strong radula it scrapes up wave-washed diatoms and algal filaments growing at the mouth of the crevice. Farther down in the crevice it is able to secure richer detritus, but its stomach contents are always finely graded, with a high proportion of diatoms, and seldom include particles of coarse detritus.

Both Otina and Leucophytia are usually present in crevices at 4 where they can evidently tolerate several hours of lowered humidity. Sometimes also at 
3 the saturation deficiency may approach that of 4 . Perhaps both species are rather better able to withstand a shorter period of greater saturation deficiency at 4 than a longer one of lesser deficiency at 3 . However, a period of humidity as low as $80 \%$ at 4 may represent a condition to which Otina and Leucophytia are not exposed for significantly long periods. Both take the fullest advantage of moist cracks where the humidity may remain locally high, and the humidity conditions of a single crevice may show wide local variations, with sheltered regions of high humidity which the thermocouple used did not reach.

The behaviour of Onchidella celtica, another primitive pulmonate which occurs in crevices of type $\mathbf{2}$ at Whitsands alongside Otina, may be compared with the above results. Fretter (1943) observed that the animals 'lived for several days in a relative humidity of $95 \%$ before showing signs of desiccation. They were quite active with the pulmonary aperture frequently open.' In $90 \%$ relative humidity they showed no apparent effect of dryness for 3 days. In $80 \%$ all after 2 days appeared shrivelled and inert. In Onchidella celtica tolerance of low humidity for limited periods is evidently great: in midAugust the animal was seen to leave the shady rock and travel over sunny surfaces. Their ratio of exposed surface to volume is of course much less than in the smaller Otina, and evaporation is probably retarded by the thick leathery integument which, aided by secretory glands, compensates for loss of shell. Animals of Otina and Leucophytia kept for I $2 \mathrm{hr}$. in a desiccator at $90 \%$ relative humidity appeared shrivelled and dried out. Fretter states that Onchidella is 'completely akinetic, making no attempt to aggregate in regions of optimum humidity when placed in a humidity gradient of $75-95 \%$.' Otina, on the other hand, reacts quickly to the equally unfavourable extremes of either a fall in the humidity of the atmosphere or of complete immersion. Jeffreys has observed (1869) that 'the animal is a restless little creature and when put into sea water crawls directly out of it.' The same active response is made when a crevice is opened and a group of Otina are subjected to the evaporating power of warm air. They crawl quickly into the shelter of a deeper part of the crevice, or, if exposed for more than 2-3 min., again become inactive, cease to crawl and clamp the shell tightly against the substratum.

The upper limit of Otina at $c$. I $5 \mathrm{ft}$. C.D. is probably governed not by reduction of food supply but by prolonged saturation deficiency. Its lower limit at EHWN is fixed by its intolerance of long submersion and its dislike of silt. Still water or submersion for more than 3 or $4 \mathrm{hr}$. seem adverse. Otina does not survive in the still waters of a tidal tank, preferring the broken and well oxygenated water received from wave-splash. Both pigmentation of the shell and the streamlined limpet shape indicate that Otina is well at home on the clean-swept outer fringe of the crevice, and is well adapted to resist both wave attack and light. Its habit of thigmotaxis, with a tendency for a group of animals to cluster together in contact, or to nestle in a barnacle shell, is probably in part an adaptation for reducing water loss by evaporation. In 
addition, the habit of negative geotaxy, clinging by preference to the upper slate of a crevice, may assist it to take advantage of the atmospheric air longer retained in this part of the crevice.

\section{Discussion \\ Ecological factors}

Any discussion of the causes affecting the distribution of crevice-dwelling animals in relation to their environment must necessarily be tentative and inconclusive. We know little at present of the mechanisms by which shore animals respond to changes in their surroundings, and distributional data are at present available only for the few localities studied in detail by the writer, and previously by Glynne-Williams \& Hobart. In the absence, however, of any attempt, before these two papers, to assess the importance of factors operating in crevice habitats, the writer felt justified in advancing the ideas induced by the present study. Their preliminary nature will be evident; and their greatest use may be to form a basis of more exact future work.

Of the ecological factors with a direct effect on the fauna of crevices, the principal ones are probably relative humidity and the presence of adequate food supply, whether in the form of organic deposits or of wave-borne microorganisms. Other factors may act to a large extent indirectly by their influence on one or other of the first two, though perhaps the effects of temperature and the dislodging power of wave action may also be direct. The most important factors influencing relative humidity are probably percentage of daily exposure, maximum longest period of exposure during a tidal cycle, maximum air temperature, incidence of breezes and amount of shade and rate of drainage of the crevice. The last two will, of course, vary complexly with the whole topography of the surrounding rock mass. With the contrasts at Wembury between southerly and northerly aspects, with crevices overthrust towards the north, both sets of factors-shelter and the structure of the rock massmay be combined in one or other of their two sets of extremes. For the majority of the fauna both factors are in their most favourable combination on the north, and most rigorous towards the south. It would be possible in rocks overthrust towards the south, with deep crevices thus facing south, to examine the effects of separating rather than combining these two factors. Relative humidity, temperature and duration of exposure are easily measured (see above), and on the moisture content and organic detritus in crevices, quantitative data have already been given by Glynne-Williams \& Hobart.

In the presence of a saturated atmosphere in crevices, the distribution of animals is likely to be governed chiefly by food supply. Here the controlling factors are probably the direct action of wave swell and splash, bringing suspended micro-organisms within the range of suspension feeders, and shifting detritus from the crevices. The influence of the surrounding rock structure is here very variable with situation, and very complex. 

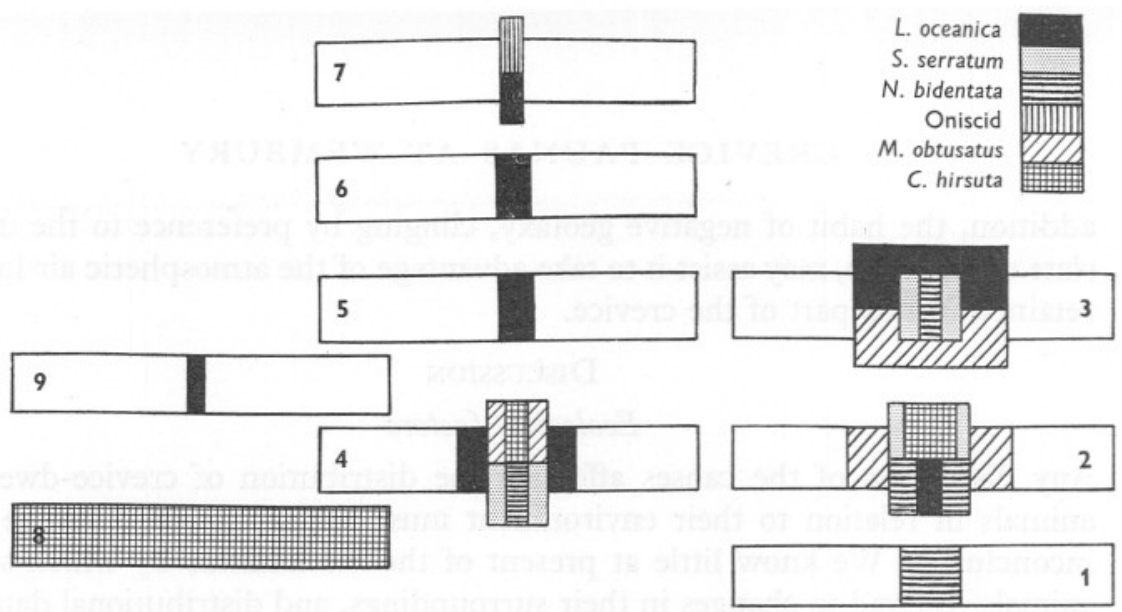

7

$H$. salinus

B. interrupta

S. maritimus

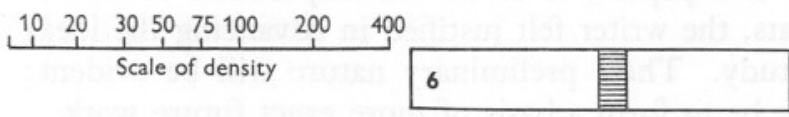

N. maritimum

5
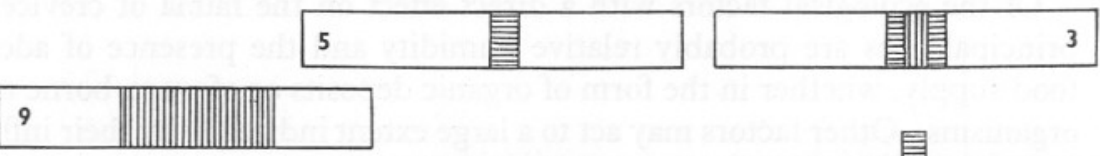

4

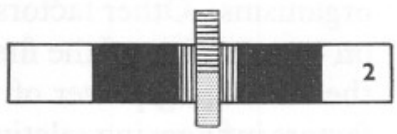

8

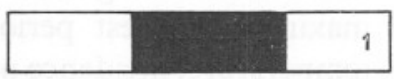

7

6

5
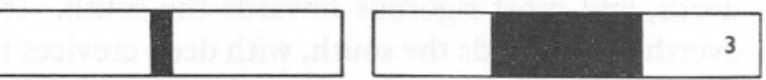

9

4

8
A. maritima

G. unicolor

A. robini

A. bonnairei

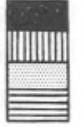

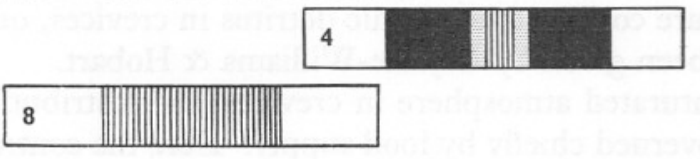

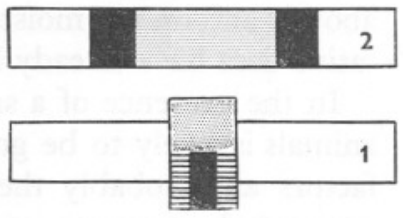

Fig. 6. Diagrams showing the quantitative distribution of twenty-two species of animals in crevices and related habitats at Wembury. The species are the following: Ligia oceanica, Sphaeroma serratum, Naesa bidentata, terrestrial oniscid, Marinogammarus obtusatus, Campecopea hirsuta; Hydrogamasus salinus, Bdella interrupta, Scolicoplanes maritimus, Neobisium maritimum; Anurida maritima, Geranomya unicolor, Aëpus robini, Aëpophilus bonnairei; Tanais chevreuxi, Lasaea rubra, Spirorbis borealis; Otina otis, Cingula cingillus, Leucophytia bidentata; Littorina neritoides, Littorina rudis. They have been arranged in 

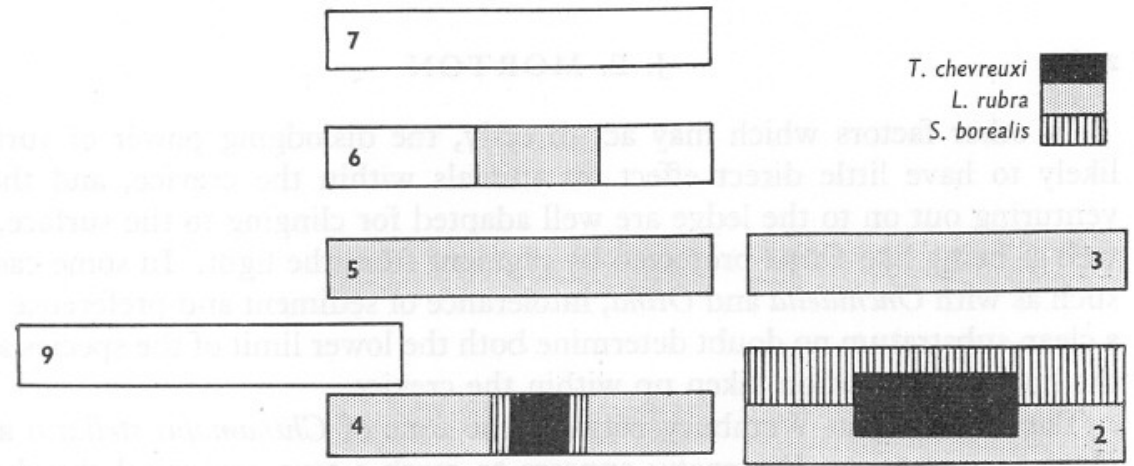

8

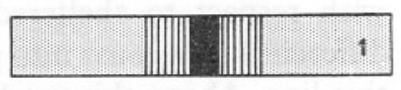

\section{7}

6

\section{5}

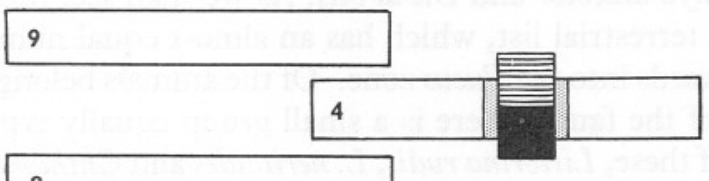

8
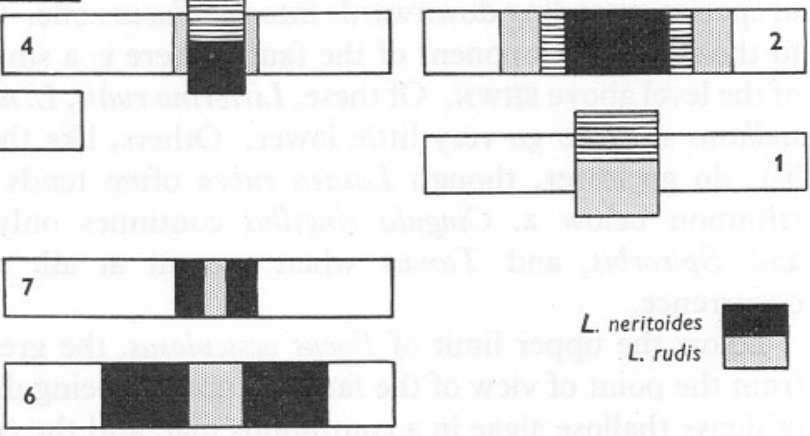

$L$. neritoides

L. rudis

10
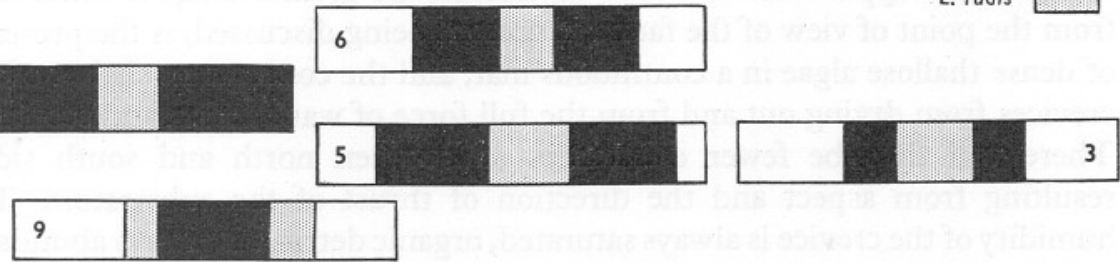

4

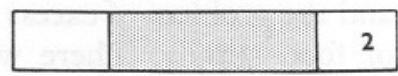

8

six groups, mostly according to approximate taxonomic relationships. Each horizontal panel represents a numbered location according to the classification adopted in the text. They are arranged in approximate sequence according to conditions of shade and height for easy reference to Fig. I. Location ro is included only in the case of the littorinids. The scale of densities adopted is shown inset. The area shaded for each species is to be regarded as extending across the middle of the panel, and the smaller areas as superimposed on, and not interrupting, the larger. 
Of other factors which may act directly, the dislodging power of surf is likely to have little direct effect on animals within the crevice, and those venturing out on to the ledge are well adapted for clinging to the surface, as well as being like Otina protected by pigment from the light. In some cases, such as with Onchidella and Otina, intolerance of sediment and preference for a clean substratum no doubt determine both the lower limit of the species and the horizontal position taken up within the crevice.

The boundary at Wembury between the zone of Chthamalus stellatus and Fucus vesiculosus or $F$. serratus appears to mark a true ecological threshold with respect to sheltered faunas living in crevices. Ecological factors of different kinds come into play, and exert the dominant roles, above and below this line. Above this mark, zonation within the crevices appears to be determined by the direct factors (i) relative humidity, and (ii) richness and adequacy of the food supply. Of the animals typical of this region, above $c$. Io ft. C.D., stopping just below EHWN, we find the two components of the fauna recognized by Stelfox (I9I6), representatives of predominantly terrestrial groups, and representatives of groups that are chiefly marine in their affinities. Of the 'terrestrial' animals here that do not also extend farther downward, there is a rather short list, Ligia oceanica, Bdella interrupta, Scolicoplanes maritimus, Anurida maritima, Geranomya unicolor and Otina otis. As we shall see, this by no means exhausts the full terrestrial list, which has an almost equal number of species extending downwards into the Fucus zone. Of the animals belonging to the marine component of the fauna, there is a small group equally typical of the level above EHWN. Of these, Littorina rudis, L. neritoides and Chthamalus stellatus seem to go very little lower. Others, like the rest of the terrestrial list, do go lower, though Lasaea rubra often tends to thin out in its distribution below 2. Cingula cingillus continues only in reduced numbers, and Spirorbis, and Tanais when present at all, show altered modes of occurrence.

Below the upper limit of Fucus vesiculosus, the great ecological difference, from the point of view of the fauna at present being discussed, is the presence of dense thallose algae in a continuous mat, and the consequent shelter of the crevices from drying out and from the full force of wave action and scouring. There will thus be fewer differences as between north and south sides, resulting from aspect and the direction of thrust of the substratum. The humidity of the crevice is always saturated, organic detritus is always abundant, and the problem of excess sedimentation takes the place of that of a deficiency of food supply. There will further be much less stratification within the crevice, of the kind which was brought about at higher levels by different amounts of drying out and wave action on detritus, with increasing depths within the crevice. In general, those animals which are able at a higher level to tolerate the heavily sedimented parts of the crevice are able to extend below the Fucus upper level, at least in reduced numbers. There is thus an overlap 
into this zone of a group of animals extending downwards below the Fucus vesiculosus upper limit, but reaching their most typical development and greatest numbers above that line. Among these may be placed Leucophytia bidentata, Cingula cingillus, Lasaea rubra and in small numbers Tanais chevreuxi. Conversely, on both sides of the line but dwindling on extent into crevices in the barnacle zone is a group of animals containing Amphitrite gracilis, Cirratulus cirratus, Perinereis marioni and probably most of the worms, with the exception of Spirorbis borealis, Lineus longissimus and Eulalia viridis which, in crevices, are more at home in the barnacle zone.

For the terrestrial element that does not extend below the lower barnacle limit, namely Otina otis, Bdella sp., Scolicoplanes maritimus and Neobisium maritimum, (though the latter is very sparse in numbers and it is difficult to be exact about its distributional limits) the limiting factor is probably increased sedimentation of the crevices which is especially important in restricting Otina. For land-derived crevice animals as a whole there does not seem to be a general lower barrier at this zone. Aëpus robini and Aëpophilus bonnairei exist happily at Wembury at the level of $\mathbf{r}$, and Glynne-Williams \& Hobart have shown their extent to or beyond MLwS at Anglesey. They no doubt retain aerial respiration as do the mite Hydrogamasus salinus and the thysanuran Anurida maritima; reliance on aerial conditions is probably possible at much lower levels and with much shorter exposures between tides than at EHWN. This group of insects, and of the mites-at least Hydrogamasus salinus, are thoroughly intertidal. Their extent into this zone is by no means dependent on a precarious compromise with marine conditions, and they are content with a short intertidal exposure for the renewal of air supplies. The arachnid Neobisium, the chilopod Scolicoplanes, the mite Bdella, and probably also the tipulid Geranomya are less well adapted for conditions in the lower intertidal zone. But, on the whole, the uppermost zone-locations $3,4,5$ and 6-is characterized in largest numbers not by members of the terrestrial element but by marine animals (Lasaea rubra, Littorina rudis, L. neritoides and Ligia oceanica) which have evolved a tolerance of longer exposure.

Of the upper limits of range of the species recorded in the present survey, the most significant is at the Fucus vesiculosus-Chthamalus stellatus boundary. A large and varied fauna of type $\mathbf{I}$ location-not in detail listed here-cuts out between crevices $\mathbf{I}$ and $\mathbf{2}$. Crevices 2 never contain, for example, ophiuroids, pilumnid or porcellanid crabs, Anomia or Hiatella. The most interesting disappearance here is that of the bug Aëpophilus bonnairei which is not a high-tidal form at all. An upper limit for a further group of species lies between crevices of types 2 and 3 . The animals disappearing here are Spirorbis borealis, Cirratulus cirratus, Amphitrite gracilis, Tanais chevreuxi, Hydrogamasus salinus, Aëpus robini and Neobisium maritimum. Leucophytia is here greatly thinned out, and we find almost the last of Otina and Cingula.

Above the level of $\mathbf{3}$ and for the most part in $\mathbf{4}$, the fauna, with the exception 
of Scolicoplanes, is not on the whole terrestrial in composition, but consists of an enterprising filter-feeding and suspension-feeding marine element like Chthamalus and Lasaea, or like the Littorinas, which are equipped with a strong scraping radula. Here they are almost entirely free of predator pressure, if this is ever indeed a significant factor, which is perhaps to be doubted in this area, with the exception of Nucella lapillus in relation to Chthamalus at its lower boundary. Animals of the terrestrial element are less adept than those above listed at obtaining their food suspended in sea water. For the most part, both for the sake of an adequate food supply and for protection from desiccation, they must go farther down in the intertidal zone and enter more fully into tidal conditions. Here they have almost all become carnivores or scavengers. The reasons for the falling out of the terrestrial element, at the highest levels surveyed, are probably connected with both food supply and humidity, disadvantages which hard-shelled, filter-feeding or radula-browsing animals have overcome.

\section{Ecological Succession}

Crevices between slates are in constant course of opening up by the loosening and ultimate detaching of a block of slate, usually the underlying one, by the action of water and weather. We have an accurate idea of the way in which a crevice may widen during the process of weathering, and though it was not possible in two seasons to detect the succession of the fauna at a single location, we can, by observing the zones present in crevices of different depths, build up a picture of the changes that must take place in the composition of a crevice fauna. Intertidal crevices provide a good example from the sea shore of an ecological succession in the words of Allee's definition (I949), 'the progressive sequence of replacement of communities over a given point, area or locality'. A crevice is first colonized as a small chink on the rock surface affording shelter to animals, and ultimately becomes deeply thrust into the rock mass before it is eliminated by the breaking away of the slate. The changes thus brought about in the substratum by weathering may be referred to as a 'physiographic succession'; the entire series of stages from bare rock through the deepening crevice with a final return to bare rock, form a 'sere'. The changes in the composition and relationships of the fauna may be regarded as constituting together the 'ontogeny' of the community. At its fullest development a crevice in Dartmouth Slate will reveal the five or six rather well defined zones illustrated in Fig. 2. As stages in succession we may recognize several phases-of colonization with the opening up and penetrating of a new crevice by successive groups of animals, new zones becoming represented with greater depth; of maturity as represented with complete horizontal zonation as in Fig. 2; and of regression by the gradual opening up and drying out of the crevice, leading to the final dropping of the slate and the re-occupation of the bare rock surface by Chthamalus and Pygmaea. It is 
difficult, without long-term observations, to estimate the rate at which succession may proceed. It is probable, however, that with the relatively rapid weathering of a foliaceous rocky substratum, the sequence of stages in Dartmouth Slate may move faster than is usual on rocky shores. The human investigator with his hammer and chisel becomes at times a biotic factor that appreciably speeds up the course of succession.

The diagram (Fig. 7) attempts to sum up the course of events at the level of a type 2 crevice, where the mature fauna is able to develop its fullest zonation. For comparison with the stages in a complete sere, we may refer to the other types of location, where the final stages represent stages intermediate in the succession at 2. Here the ecological conditions are seldom favourable to give expression to all the stages of a complete sere. Thus, each of the types $3,4,5,6,7$ and 8 broadly correspond to stages passed through in the development of a crevice at location 2. At stage (i) in the suggested succession, a small chink is established in the slate, and barnacles at once extend into it, together with Littorina neritoides and L. rudis. Pygmaea also takes advantage of the shaded surface overhanging the crevice above, though it normally reaches only just to the typical level of 2 . A comparison of this stage may be made with locations of types 7 and 8 . Wherever Pygmaea grows a little detritus lodges deeper to it, so that at (ii) Lasaea rubra is able to nestle in a protected niche, with still a few Littorina neritoides as before, even in the slightest chink, but generally with a predominance of L. rudis. Scolicoplanes maritimus can lodge itself deeply in the extending crack, and Ligia shelters here and runs about freely on the exposed surface. Comparison may be made between this stage and the final condition at locations $\mathbf{5}$ and $\mathbf{6}$.

At (iii) the crevice has pushed back a little farther, more organic material has accumulated together with an admixture of fine sand, and Tanais becomes established in its galleries to form the zone lying deepest, with, immediately outside it, Lasaea, now accompanied by Cingula and a few Leucophytia (cf. location type 4). At (iv) the weathering has extended deeper. The Tanais zone tends to be pushed back as always to the narrowest, most recently opened parts, though there is sometimes, as in the complete succession, a zone of muddy sand or inorganic weathering products inhabited by deposit-feeding worms whose tentacles extend through gaps in the Tanais zone. Farther outwards in the crevice there is now room for members of the zone (C) of Fig. 2, with Leucophytia, Cingula, Sphaeroma, Naesa and most numerous of all, Lasaea rubra. Still farther out becomes established the innermost lighted zone (B), which is open enough not to be clogged with detritus. Here there is an encrusting mantle of Spirorbis and Ralfsia, and Otina is best developed here as well as extending into zone (C).

At maturity the crevice is established with its full zonation as shown at Fig. 2. Regression of zonation takes place upon further opening up and drying out of the crevice, by the action of greater wave-scouring, and penetra- 


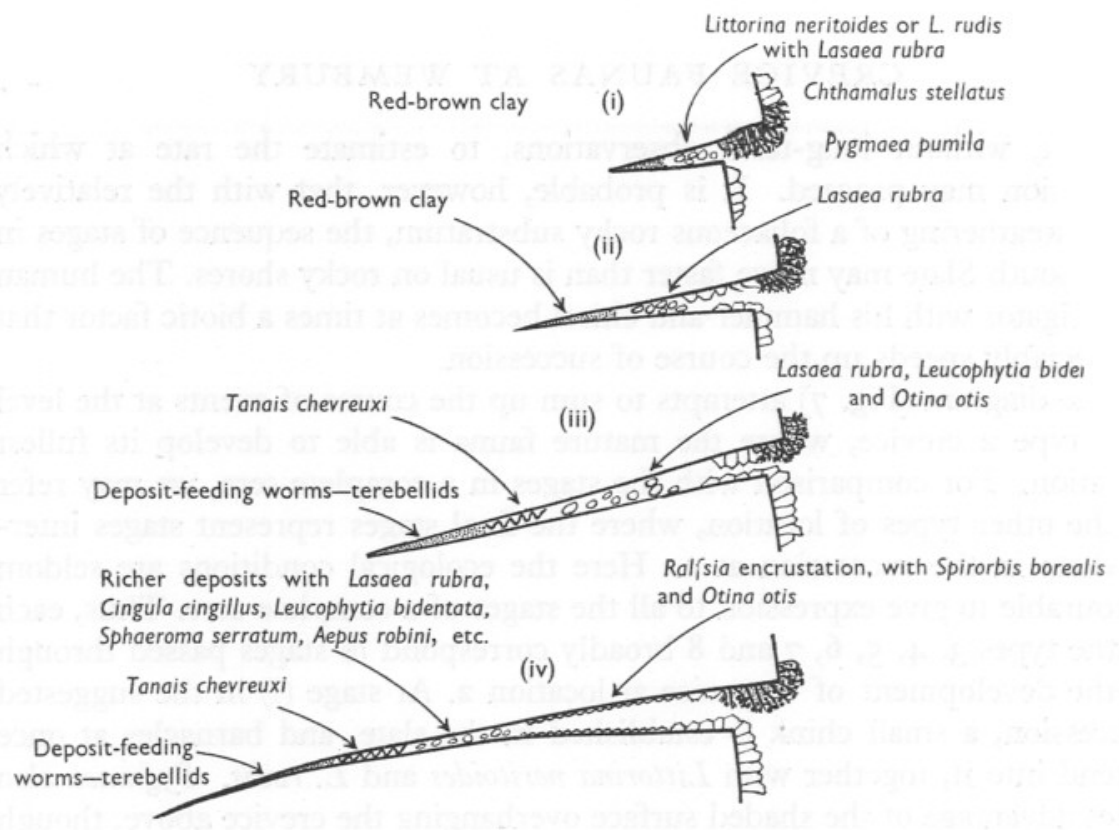

(v)
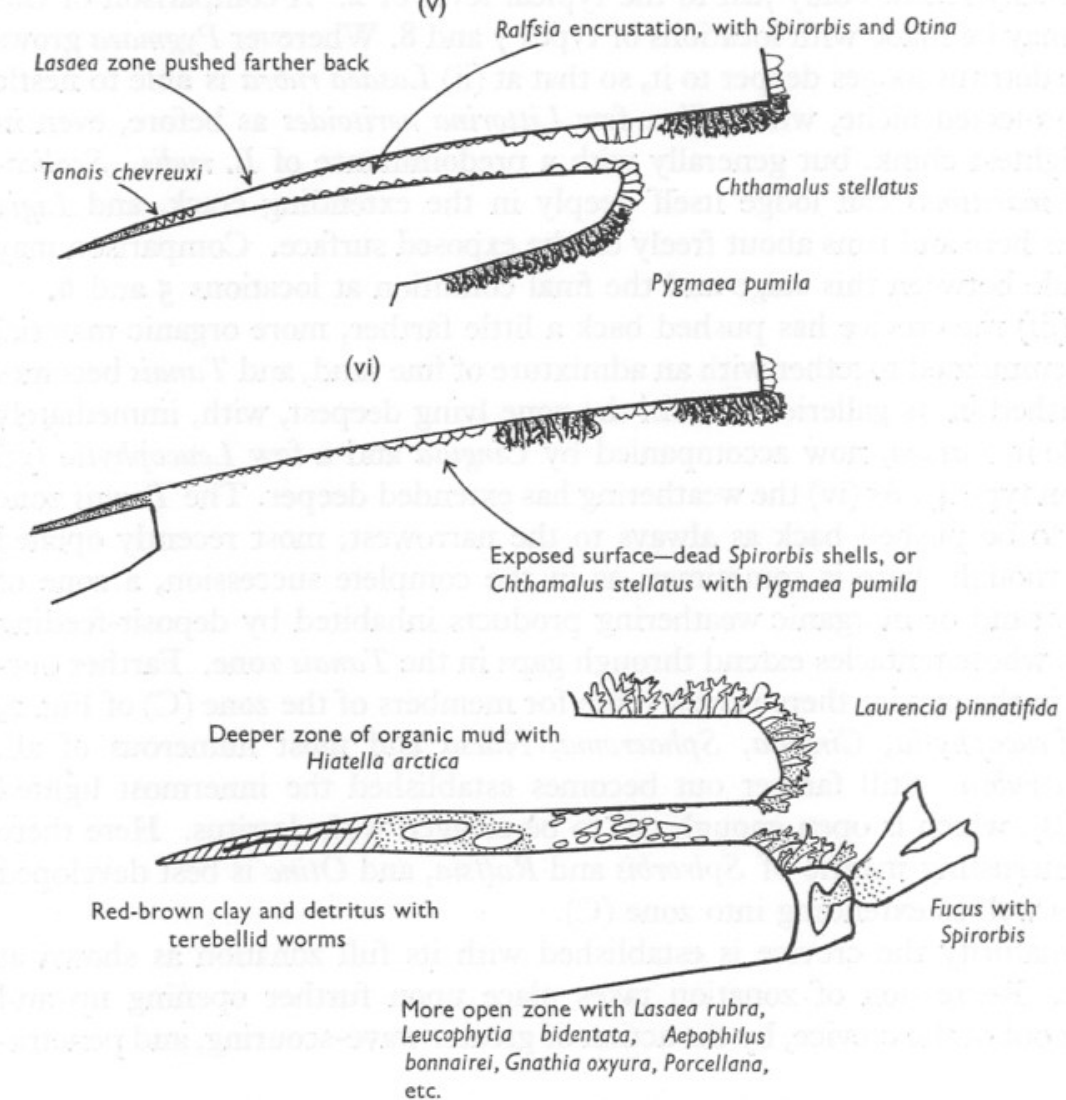

Fig. 7. Scheme to illustrate the course of ecological succession, (i) to (vi), as shown by crevice faunas at a type $\mathbf{2}$ location at Wembury. The lowest figure shows for comparison a crevice in the fucoid zone (location $\mathbf{r}$ ). 
tion of the heat of the sun. The level of zones (B) and (C) is all the time pushed farther back, while at the bottom of the crevice where the slates are almost in contact is a fragmentary or complete zone of Tanais (D). Sometimes extending behind the Tanais, at times intermixed with (C), is the zone (E) inhabited by deposit-feeding terebellids.

With still greater loosening of the slate (vi) the crevice may become too open to wave-scouring to retain rich deposits, and during exposure to air the humidity of its atmosphere may fall. In such a crevice Ligia, Littorina rudis and sometimes Gibbula umbilicalis of the outer zone are able to push in more deeply, and the zone (C) of Lasaea moves towards the bottom of the crevice, with Leucophytia, Otina and Tanais tending to be lost. As a final stage of weathering, the whole lower slate may break away, and the under surface of the topmost slate may then sometimes remain encrusted with dry Spirorbis shells, or-at a higher level-acquire barnacles and tufts of Pygmaea.

Locations of type $\mathbf{I}$, as has been pointed out, fit less well into such a system as is outlined above. These crevices have a longer submergence, and are more permanent, with a more stable and less obvious zonation within. The chief ecological feature is the much greater silting-up and the permanent waterlogging of the deposit. The communities consist of a narrow zone of Laurencia, spreading into the mouth in place of Pygmaea, an open silted zone with porcellanid crabs, ophiuroids, etc. (see p. 20I), and finally a zone of compacted sand and detritus where Hiatella and deposit-feeding worms are typical.

\section{Comparison with other localities}

Glynne-Williams \& Hobart (I952) discussed the faunas of crevices in green mica schists. Both here and at another locality examined in the Plymouth area, the Dartmouth Slate reef at Whitsand Bay, the mode of foliaceous weathering and the succession and composition of the fauna seem to be essentially the same as at Wembury. Two unexplained local differences at Whitsand Bay are the presence there, alone in the Plymouth area, of Onchidella celtica, and the replacement of Cingula cingillus by its white variety rupestris. At the two Dartmouth Slate localities, the crevices are probably on an average deeper than at Anglesey, which may account for the greater range of horizontal zonation. Five inhabited zones could be recognized, of which the first two probably best correspond to Glynne-Williams \& Hobart's 'outer zone', the remainder to their more heavily silted 'inner zone'. Crevice faunas have also been examined at Rum Bay and Jennycliff Bay (Staddon Grits), Drake's Island (igneous intrusion), and Kingsand (felsite). Here, the large blocks of rock develop narrow vertical joint planes, and though the fauna is similar to fragments of the Wembury zonation, the full succession seems to be seldom developed.

The chief feature of the fauna lists for the Plymouth area and for North Wales is the detailed similarity in composition and in the dominant species 
represented. Thus for the intertidal fauna, Lasaea rubra, Littorina rudis, Cingula cingillus, Leucophytia bidentata, Ligia oceanica, Campecopea hirsuta, Sphaeroma serratum, Anurida (bisetosa in North Wales, maritima here), Cyrthydrolaelaps hirsutus, Bdella interrupta, Hydrogamasus salinus, Neobisium maritimum, Scolicoplanes maritimus and Eulalia viridis are all characteristic of both regions. Aëpus robini, Aëpophilus bonnairei and Gnathia oxyuraea are equally characteristic at a lower level. This list may probably be a familiar one on most British shores of similar formation, and, as remarked by Glynne-Williams \& Hobart, the greater number of its species are those not commonly found outside crevices. We find, as it were, a 'crypto-zonation' in crevices, equally characteristic with the zonation on exposed surfaces. With the damping down of differences in wave action, light and evaporation, zonation in crevices may be more uniform over considerable vertical heights than the surface zonation. Nevertheless, with differences in aspect and in depth of crevices, many gradations are brought about, and-in particular, the influence of aspect and topography-makes the concept of 'critical levels' of less value, with its demarcation of zones more strictly in terms of tidal level.

One or two important absences of Plymouth animals from the Anglesey list of crevice fauna may be noted. Spirorbis is not stated to play any part in crevice communities, and there is no mention at all of Littorina neritoides at higher levels. Its lack of mention is probably due to the smaller emphasis placed by Glynne-Williams \& Hobart on the distinctive features of crevices in the upper part of the zonation. Otina otis and Tanais chevreuxi are evidently entirely absent at Anglesey. Tanais seems roughly to be replaced ecologically by Apseudes talpa, which was not found at all in crevices at Plymouth.

Otina otis has a rather restricted geographical distribution, being a northwest European and British species only. Jeffreys (1869) gives Normandy, Brest, Quiberon, Piriac and Loire Inférieure for its French distribution, and in England the Devon and Cornish coasts. It extends to south Wales, south and north Eire and Northern Ireland. Moore (1937) records it on the Isle of Man. Otina otis is evidently a southern species and its range would seem in Britain to follow fairly closely that of Chthamalus stellatus with which it lives in fairly intimate association. It is apparently absent, however, from the north Scottish coast, accompanying Chthamalus only as far as the Firth of Clyde. At Carmel Head and North Stack, Anglesey, Chthamalus was found by Southward (I95I) at its minimal distribution for the Irish Sea, and no Otina at all were noticed by Glynne-Williams \& Hobart. The range of Otina in the English Channel a little exceeds that of Chthamalus, and a record by Jeffreys of a dead shell from Northumberland seems to require reinvestigation.

It is possible to suggest a tentative scheme of crevice zonation, based on the Plymouth results, which may with some modifications, as at Anglesey, be found to hold good over a large part of British shores where the nature of the rock mass is suitable to it. The following regions can be defined in terms of 
approximate tidal levels, though these are subject to wide variation, and the sequence of zones is always most complete on the shaded overhanging side, and modified as has been shown on the unshaded side.

(i) Above EHws, where Littorina neritoides is dominant and often alone.

(ii) From MHWs to MHWN, where $L$. rudis enters into the zonation with neritoides and Lasaea rubra become abundant and dominant. Ligia oceanica is also highly typical, and associated with Chthamalus stellatus appears the marine pulmonate Otina otis.

(iii) MHWN to the bottom of the Chthamalus zone, where the Littorinas drop out, and a numerous deposit-feeding element appears. Lasaea rubra is completely dominant; deposit feeders like Leucophytia bidentata, Cingula cingillus and Otina otis are most abundant here, and Spirorbis, Eulalia viridis, Aëpus robini and Hydrogamasus are typical.

(iv) A special habitat at the same level, the tufts of Pygmaea pumila, still dominated by Lasaea rubra which is accompanied by Geranomya unicolor and Campecopea hirsuta in vast numbers.

(v) A zone of changed conditions below the Fucus vesiculosus upper limit, where Otina and Tanais disappear and Cingula cingillus thins out. There is a continued dominance of Lasaea rubra, abundance of Leucophytia, Aëpus and Hydrogamasus, and a new appearance of Aëpophilus, Porcellana, Hiatella, Gnathia and many other low-tidal forms.

\section{SUMMARY}

This paper presents the results of a study of the animals dwelling in crevices and related habitats on the upper portion of an intertidal reef of Dartmouth Slates at Wembury. The oblique overthrust of the slates towards the north provides a series of habitats on the north and south aspects differing in respect of exposure to the sun and to wave action, and in the depth of the crevice and the composition of its substrate. A series of ten types of microhabitat has been recognized, and an account given of the quantitative distribution and mode of occurrence of the typical species of animals present at each type of location. The nature is discussed of the horizontal zonation within a typical crevice under the most favourable conditions on the shaded side. Fuller ecological notes are provided for several of the ecologically more important species, especially the molluscs Lasaea rubra, Leucophytia bidentata and Otina otis. Of the environmental factors, temperature and relative humidity during the time of exposure have been measured at intervals throughout a single intertidal period. A tentative discussion is given of some of the ecological factors which may be of limiting importance in these habitats, and a scheme is presented of the probable course of ecological succession with the weathering of the rocky substratum and the progressive deepening of the crevice. 


\section{REFERENCES}

Allee, W. C. et al., 1949. Principles of Animal Ecology. Philadelphia and London. Buxton, P. A. \& MellanBy, K., I934. Measurement and control of humidity. Bull. ent. Res., Vol. 25, pp. I7I-5.

Colman, J. S., I932. The nature of the intertidal zonation of plants and animals. F. Mar. biol. Ass. U.K., Vol. I8, pp. 435-76.

- 1940. On the faunas inhabiting intertidal seaweeds. F. Mar. biol. Ass. U.K., Vol. 24, pp. 129-83.

Dennell, R., I937. On the feeding mechanism of Apseudes talpa and the evolution of the peracaridan feeding mechanisms. Trans. roy. Soc. Edinb., Vol. 59, pp. 57-78.

Evans, R. G., I947. The intertidal ecology of selected localities in the Plymouth neighbourhood. F. Mar. biol. Ass. U.K., Vol. 27, pp. I73-218.

FRETTER, V., I943. Studies in the functional morphology and embryology of Onchidella celtica (F. and H.) and their bearing on its relationships. F. Mar. biol. Ass. U.K., Vol. 25, pp. 685-720.

GlynNe-Williams, J. \& Hobart, J., I952. Studies on the crevice fauna of a selected shore in Anglesey. Proc. zool. Soc. Lond., Vol. 122, pp. 797-824.

Jefrreys, J. G., I869. British Conchology. London.

Marine Biological Association, 1931. Plymouth Marine Fauna, and ed.

Moore, H. B., I937. Marine fauna of the Isle of Man. Proc. Lpool biol. Soc., Vol. 50, $293 \mathrm{pp}$.

Nicholls, A. G., I93 I $a$. Studies on Ligia oceanica. I. A. Habitat and effect of change of environment on respiration. B. Observations on moulting and breeding. 7. Mar. biol. Ass. U.K., Vol. 17, pp. 655-73.

- I93 $b$. Studies on Ligia oceanica. II. The processes of feeding, digestion and absorption, with a description of the structure of the foregut. F. Mar. biol. Ass. U.K., Vol. 17, 675-707.

Orton, J. H., 1929. Observations on Patella vulgata. III. Habitat and habits. F. Mar. biol. Ass. U.K., Vol. 16, pp. 277-88.

Popham, M. L., I940. The mantle cavity of some of the Erycinidae, Montacutidae and Galeommatidae, with special reference to the ciliary mechanisms. F. Mar. biol. Ass. U.K., Vol. 24, pp. 549-87.

SOUTHWARD, A. J., I95I. The distribution of Chthamalus stellatus in the Irish Sea. Nature, Lond., Vol. I67, p. 4Io.

Stelfox, A. W., I9I6. Otina otis on the Co. Down Coast. Proc. malacol. Soc. Lond., Vol. 12, p. 318.

Stephenson, T. A. \& Stephenson, A., 1949. The universal features of zonation between tidemarks on rocky coasts. F. Ecol., Vol. 38, pp. 354-402.

WIESER, W., I952. Investigations on the microfauna of seaweeds inhabiting rocky coasts. F. Mar. biol. Ass. U.K., Vol. 31, pp. 145-74. 